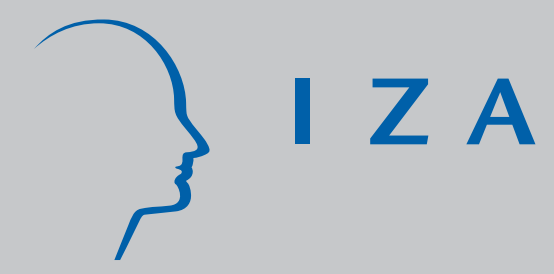

IZADP No. 3993

Workplace Disability Diversity and J ob-Related Well-Being in Britain: A WERS2004 Based Analysis

Getinet A. Haile

February 2009 


\title{
Workplace Disability Diversity and Job-Related Well-Being in Britain: A WERS2004 Based Analysis
}

\author{
Getinet A. Haile \\ $P S I$ and IZA \\ Discussion Paper No. 3993 \\ February 2009 \\ IZA \\ P.O. Box 7240 \\ 53072 Bonn \\ Germany \\ Phone: +49-228-3894-0 \\ Fax: +49-228-3894-180 \\ E-mail: iza@iza.org
}

Any opinions expressed here are those of the author(s) and not those of IZA. Research published in this series may include views on policy, but the institute itself takes no institutional policy positions.

The Institute for the Study of Labor (IZA) in Bonn is a local and virtual international research center and a place of communication between science, politics and business. IZA is an independent nonprofit organization supported by Deutsche Post Foundation. The center is associated with the University of Bonn and offers a stimulating research environment through its international network, workshops and conferences, data service, project support, research visits and doctoral program. IZA engages in (i) original and internationally competitive research in all fields of labor economics, (ii) development of policy concepts, and (iii) dissemination of research results and concepts to the interested public.

IZA Discussion Papers often represent preliminary work and are circulated to encourage discussion. Citation of such a paper should account for its provisional character. A revised version may be available directly from the author. 


\section{ABSTRACT}

\section{Workplace Disability Diversity and Job-Related Well-Being in Britain: A WERS2004 Based Analysis*}

This paper attempts to establish empirically whether there is a link between workplace disability and employee job-related well-being. Using nationally representative linked employer-employee data for Britain, I employ alternative econometric techniques to account for unobserved workplace heterogeneity. I find that workplace disability diversity is associated with lower employee well-being among people with no reported disability. Tests conducted also indicate that workplace equality policies do not ameliorate this effect.

JEL Classification: $\quad \mathrm{J} 14, \mathrm{~J} 82, \mathrm{~J} 7, \mathrm{I} 31$

Keywords: disability diversity, job-related well-being, linked employer-employee data, Britain

Corresponding author:

Getinet A. Haile

Policy Studies Institute

London W1W 6UP

United Kingdom

E-mail: g.haile@psi.org.uk

\footnotetext{
* This paper constitutes part of the output from the research project investigating workplace diversity and employee job-related well-being in Britain, which is funded by the Economic and Social Research Council under ESRC grant RES-000-22-2465. The author is grateful for the grant and would like to thank the ESRC. The author also acknowledges the Department of Trade and Industry, the Economic and Social Research Council, the Advisory, Conciliation and Arbitration Service and the Policy Studies Institute as the originators of the 2004 Workplace Employment Relations Survey data, and the Data Archive at the University of Essex as the distributor of the data. The National Centre for Social Research was commissioned to conduct the survey fieldwork on behalf of the sponsors. None of these organisations bears any responsibility for the author's analysis and interpretations of the data. I would like to extend my sincere thanks to Michael White, Alex Bryson and Helen Bewley for insightful discussions and useful feedback on earlier drafts of the paper and Hirut Mengistu for research assistance. Early findings were presented at the 2008 WERS-WPEG meeting in Sheffield and the 2008 SOLE conference as well as seminars in WBS, Cardiff, Mannheim, PSI and DWP. I would like to thank participants at these events for useful comments. The usual disclaimer applies.
} 


\section{Introduction}

There is a dearth of empirical research on workplace disability. Research in this area is vital for a number of reasons. First, there is evidence that the number of people claiming incapacity benefits in Britain has trebled since the 1970s. Britain also has large numbers of disabled people and people with long-term illness, compared with other European countries. Moreover, proportionately fewer of these people are in employment (Blekesaune 2007, 2006; EHRC 2008). It is imperative that research establishes if there are workplace related factors contributing to this trend. This will inform the current policy drive to move more disabled people and people with long-term illness into employment. Secondly, there is evidence on discrimination on the basis of health and disability in Britain (EHRC 2008, Berthoud and Blekesaune 2007, Madden 2004, Jones et al. 2003). This is despite existing legislative and/or workplace equality provisions aimed at people with long-term illness and disability. This evidence may also mean that nondisabled workers experience some sort of well-being penalty, particularly if the presence of disabled co-workers is something 'imposed', for example, by labour cost considerations. There is a need for research to establish the effectiveness of workplace policies and the nature of unfavourable experiences the disabled face. Equally, it is important to establish whether having disabled co-workers has some implications for the well-being of their non-disabled counterparts. Third, the few studies on workers with disability focus on employment disadvantage. There is hardly any evidence relating to whether disability at the workplace has any bearing on the well-being of employees, disabled or otherwise. It is vital that research fills this gap to help inform (i) initiatives aimed at increasing the labour market participation of disabled people and (iv) measures aimed at improving workplace well-being and/or curtailing ill-health and disability at the workplace.

This paper attempts to investigate whether there is a link between workplace disability diversity and the well-being of employees. The main hypothesis of the paper is that if discrimination on the grounds of disability is widespread, the growing emphasis on diversity - particularly if this is driven by labour cost considerations, rather than by active equality policies supplementing anti-discrimination legislations - could well have adverse effect on employees' job-related well-being. ${ }^{1}$ Job-related well-being is an integral part of

\footnotetext{
${ }^{1}$ Job-related well-being is what people feel about themselves in relation to their job while context free or overall well-being relates to feelings in any setting, having broader focus. "Both forms of well-being are located within the broader concept of mental health" Warr (1999, p. 393).
} 
overall well-being, and both types of well-being are located within the broader concept of mental health (Rode 2004, Warr 1999). Establishing the link between workplace disability diversity and employee job-related well-being will thus also be informative of how the former is related to employees' overall well-being. Crucially, this may also inform the policy drive to move disabled people into work, as well as testing the effectiveness of existing equality policies. These measures may prove futile if: ( $\imath$ disabled employees face unfavourable experiences at work that might worsen their situation or (ii) their participation in the labour market somehow reduces the well-being of their non-disabled counterparts adversely, or (iii) both. More importantly, there could be circumstances under which adverse effects of disability diversity on job-related well-being could be ameliorated. $^{2}$

The paper is unique in several important respects. First, I use the WERS2004 data, which is a nationally representative linked employer-employee data, which are best suited to investigating whether workplace disability diversity has any bearing on employee well-being. The data have large number of demographically varied workplaces located across Britain. The linked data also have comprehensive information on workplaces, employees, and human resource management practices related measures. This allows controlling for extensive set of observable influences on well-being, including workplace contextual influences than has been done in similar studies before. Secondly, the data have extensive sets of measures on employee job-related well-being that include eight measures of facets of job satisfaction and a further six measures of affective wellbeing. ${ }^{3}$ This enables investigating links between disability diversity and aspects of workplace well-being hitherto unexplored. Third, I use an index of workplace disability diversity, defined as one minus the sum of the squared shares of disabled and nondisabled employees in a workplace, to measure disability diversity. The use of disability diversity index defined in this way allows accounting for nonlinearities that simple proportions would not capture. Fourth, the paper exploits the nested structure of the WERS2004 data to control for unobserved workplace heterogeneity. One important lesson that research in labour economics, particularly where there is a matched employeremployee data, underscores is the importance of unobserved factors in determining labour market outcomes (see, for example, Abowd et al. 1999). In the workplace setting

\footnotetext{
${ }^{2}$ For example, Kochan $e t$ al. (2003) reported adverse effects of racial diversity on team processes being mitigated through training and development-focused initiatives.

${ }^{3}$ Affective well-being is thought to indicate the frequent experience of positive affects and the infrequent experience of negative affects (Daniels 2000).
} 
considered here, there may well be unmeasured aspects of workplaces that influence employee job-related well-being. This makes accounting for unobserved workplace heterogeneity essential. I also use alternative econometric models and, in each case, estimate models with several specifications as robustness check.

\section{Related theory and research}

\subsection{Theoretical background}

There are alternative theoretical explanations across the different streams of social sciences that can provide a framework for analysing the link, if any, between workplace disability diversity and employee job-related well-being. ${ }^{4}$ In the economics context, the relevant theoretical explanations largely relate to theories of discrimination. In this regard, the leading explanations are those that relate discrimination to either preference (Becker 1957; Arrow 1972, 1973; Phelps 1972) or information (Aigner and Cain 1977). The former stipulates that discrimination occurs when people behave as if they refuse to change their stereotypes about the capabilities of discriminated individuals or groups, in this case the disabled. It is to do with taste and may not change in the face of favourable information about the group, for example regarding their capability to carry out job tasks as good as the non-disabled. The information explanation (Aguero 2005), on the other hand, states that (employer) discrimination is the result of asymmetric information regarding (the productivity of) the discriminated individual and such stereotypes alter with information. ${ }^{5}$

Akerlof and Kranton (2000) formalized the earlier "taste" based discrimination explanations by incorporating identity into a model of behaviour and showing how identity influences economic outcomes. Their formulation is based on social identify theory that posits that an individual's social identity depends on all of the identifications the person uses in construing her/his views of the self. ${ }^{6}$ According to these explanations, a person experiences anxiety when the person's internalised rules of personality (or identity or ego or self) are violated somehow. Alesina and La Ferrara (2000, 2005) also note how diversity may affect economic choices by directly entering individual behaviour/preferences. Their formalization of the social identity theory based

\footnotetext{
${ }^{4}$ These include theoretical explanations from economics, organisational management, sociology, and social psychology. However, these explanations do not necessarily come up with the same prediction regarding how demographic composition affects job-related well-being.

${ }^{5}$ Other, theories of relevance include language (difference) based discrimination (Lang 1986) and Lazear (1999)'s communication costs explanation of (racial) diversity.

${ }^{6}$ See Tajfel (1982), Turner (1987), Stone-Romero et al. (2006).
} 
on group participation predicts that individual utility from joining a group depends positively on the share of group members of one's own type and negatively on the share of different types.

Unlike the earlier (taste-based discrimination) theoretical explanation, which is primarily aimed at explaining racial discrimination, these 'social identify' based formalizations allow addressing other types of discrimination such as those based on disability. The social identity of a person is based up on such things as membership to a group the person belongs or thinks to be part of, which inevitably creates an out-group that is real or imagined. To the extent that an individual, say, for example, a disabled person, is considered as out-group member, the disabled may be regarded as a threat to the well-being of non-disabled individuals (Stone-Romero et al., 2006). In a workplace setting in particular, where competition (for example, for promotion) may be the rule rather than the exception, this may lead to strained interpersonal relations. In turn, these reduce workplace well-being.

Based on Becker (1957) and Akerlof \& Kranton (2000), and building on Ragan and Tremblay (1988), I formulate a simple framework to study how workplace disability diversity may influence employee job-related well-being as follows:

Assumption 1: There are two groups of workers $D$, disabled, and $N$, nondisabled in a workplace.

Assumption 2: Non-disabled (N) workers have a "taste for discrimination" against disabled $(D)$ workers, whom they regard as a threat.

Two types of predictions follow from this, which I can test empirically. First, assume that the well-being effect of workplace disability diversity does not vary with the degree of disability diversity so that;

$$
w_{N}=(1-d i) w_{D}
$$

where $w$ stands for job-related well-being; $0<d<1$ and $i=1$ if the workforce has at least one disabled employee and 0 otherwise. Secondly, assume that the link between disability diversity and job-related well-being varies with the degree of disability diversity 
at the workplace. In this case, one could assume the job-related well-being of $N$ workers to be a negative function of the proportion of the $D$ workers, i.e.

$$
w_{N}=f\left(e_{D} / e_{T}\right)
$$

where $f^{\prime}<0$ and $e_{T}$ is the sum of non-disabled and disabled workers. ${ }^{7}$ If Alesina and La Ferrara (2000, 2005)'s prediction holds, the increase in the numerator of equation (2) may mean more strained relations between disabled and non-disabled workers and one should expect accelerated decline in the well-being of non-disabled workers, i.e., $f^{\prime \prime}<0$.

Based on this theoretical framework, one could put forward the following hypotheses, which I test in the empirical analyses that follow:

Hypothesis 1: disability diversity leads to lower employee well-benig

This hypothesis will be tested on the basis of the estimated coefficient (and significance) of the main disability diversity variable for each of the employee job-related well-being equations I estiamte.

Hypothesis 2: the lower employee well-being bypothesis 1 alludes to is associated with non-disabled employees.

The social identify explanation and relative group size help formulate this hypothesis. The disabled are generally a minority either at the workplace setting or, for that matter, outside of it. Accordingly, they are more likely to form members of the outgroup, somehow reducing the well-being of in-group members (the non-disabled). This hypothesis could be tested on the basis of either a sub-group analysis based on disability status or from the interaction of the disability indicator and the disability diversity index. I do the former in this paper.

Hypothesis 3: the adverse well-being effect of disability diversity on the nondisabled increases with the level of disability diversity. That is, as the relative

\footnotetext{
${ }^{7}$ As explained in the methodology section, simple proportions fail to capture the full extent of workforce disability diversity. I therefore use an index of disability diversity, instead of disability proportions.
} 
size of disabled employees increases, the reduction in the well-being of the non-disabled increases

This hypothesis is based on the prediction made by Alesina and La Ferrara $(2000,2005)$, where it is stipulate that individual utility from joining a group depends on the share of group members of one's own type. This could be tested on the basis of dummy variables signifying different/increasing levels of the disability diversity.

Hypothesis 4: I hypothesise workplace policies and practices to have either of the following two outcomes:

Hypothesis 4 a: workplaces with active equality/diversity policy and practice, including staff training focused on creating awareness on the capabilities of disabled workers, would ameliorate the adverse well-being effect of disability diversity

Hypothesis $4 b$ : workplaces with a policy and practice that only pays lip-service would fail to ameliorate the adverse effects of disability diversity.

I test for these hypotheses by incorporating interaction terms of the disability diversity variable and a summary measure of the policy and practices in place at the workplace. This would tell me whether on balance these workplace policies are effective.

\subsection{Review of the literature ${ }^{8}$}

One consensus among the few existing studies on the theme of disability is the lack of research in the area in general. ${ }^{9}$ This is despite striking statistics on the size of the disabled population in the UK and the potentially huge benefit from research into this area. Some 20 percent of people of working age in private households in Britain have long-term disability; fewer than 50 percent of the disabled are in employment vis-à-vis an employment rate in excess of 80 percent for the non-disabled. Approximately 50 percent of the disabled population in the UK are economically inactive vis-à-vis 15 percent of the non-disabled (Smith and Twomey 2002, ONS 2003, Kersley et al., 2006). As stated earlier

\footnotetext{
${ }^{8}$ It is essential to note that existing studies on diversity refer to the relationships between measures of diversity and various outcomes of interest as 'effects' and/or 'impacts' although they do not establish causation between the two. This section reports the review of existing literature as it is.

${ }_{9}$ There is a disquieting lack of academic research in the area both in the UK and elsewhere. Stone-Romero et al., (2006), for example, state "despite the growing number of PWD in the United States, relatively little research has focused on disability issues" (p. 402) (PWD=people with disability).
} 
there has been an increasing trend in the number of people with disability in Britain over the last few decades, based on incapacity benefit claimant figures. Compared with other European countries Britain also has large numbers of disabled people and people with long-term illness, although figures on the proportion of the disabled population are comparable to that of the USA (Blekesaune 2007, 2006; Stone-Romero, et al., 2006, EHRC 2008).

It is obvious that there is wide variation among the disabled population in terms of the nature of disability condition limiting involvement in labour market activity. Notwithstanding such variation, however, the disabled constitute a large proportion of the labour force. Disability conditions permitting, comparable (to the non-disabled) involvement in the labour market of the disabled would make considerable economic sense. This underlies the various initiatives by policy makers for a fuller integration of the disabled. ${ }^{10}$ The success of such initiatives depends, among other things, on how the disabled are accommodated at the workplace. The work environment on the whole and the different actors therein - employers, employees and customers - could play a crucial role in this process.

As noted earlier, there is a dearth of research on disability issues, particularly in the context of the workplace. However, the few existing studies point towards disabled workers experiencing disadvantage at work. Reported disadvantages relate to how disabled workers fare vis-à-vis their non-disabled counterparts in terms of layoff, (re-) employment, wage/earnings, and promotions, among others (Baldwin and Schumacher 2002, Jones et al. 2003, Madden 2004, Kersley et al., 2006, Berthoud and Blekesaune, 2007, Berthoud 2008). In a study of oblique interest to this paper, Disney et al. (2006) establish a link between ill-health and retirement, which, in some cases at least, may mean disguised layoff for people with ill-health (and disability). The levels of disadvantages reported may well vary by the type of disability considered and/or how it is measured (Berthoud and Blekesaune, 2007). Nevertheless, there is sufficient evidence to suggest unfavourable treatment at work.

Why disabled workers face such penalties is of course the key question that needs to be explored. There is some research that points to stereotypes and associated stigmas playing a key role in this. Stone-Romero, et al. (2006) report a number of research on this and attribute some five reasons why employers may be concerned with disabled workers including: ( $($ ) they may not have the skills and abilities required to perform their

10 The Disability Discrimination Act (1995) and the various welfare reform initiatives by DWP could be examples. 
job, (ii) they increase the demands placed on supervisors, (iii) they create inequality in the workplace because of needed accommodations, (iv) they increase health care costs, and (v) they have low levels of emotional adjustments that are reflected through indicators of bitterness, nervousness and depression. Stone-Romero, et al. (2006), however, present evidence that these employer views are unfounded and that research has consistently found that disabled workers have many talents and skills that can add significant value in the workplace. There is, for example, some evidence suggesting that "disabled workers have lower turnover and absenteeism rates, and perform as well, if not better, than people without disability" (p. 402). The above stereotypes and associated stigmas are, of course, specific to the employer. There are also stereotypes and associated stigmas related to co-workers, clients and customers that disabled workers face (EHRC, 2008). In some sense, unfavourable treatment by co-workers may be more damaging if this leads to isolation and/or confrontation on a sustained basis with adverse implications for workplace well-being. Alternatively, if employees with disability are viewed as out-group members and a 'threat' to members of a (majority) in-group, this may have adverse wellbeing implications for the latter.

It is noteworthy that there is no evidence to date on whether disability has any well-being implications in a workplace setting. This study aims to fill this gap in existing knowledge by studying links between workplace disability diversity and employee (psychological) well-being. As well as being one of the first to look into workplace disability diversity and its effect on well-being, the paper uses extensive measures of workplace well-being some of which unexplored hitherto. As detailed in the data section, I use eight facets of job satisfaction and six measures of job-related affective well-being to explore whether there is a link between workplace disability diversity and employee well-being. Daniels (2000) notes that work-related psychological well-being has been defined narrowly as job satisfaction and suggests using affective well-being measures to overcome this weakness. It is widely noted in the psychological literature that affective well-being reflects the frequent experience of positive affects and infrequent experience of negative affects. Measures of affective well-being are considered among the most important, if not the most important, measures of psychological well-being (Daniels 2000, Warr 1994, Diener and Larsen 1992). ${ }^{11}$

As well as using extensive measures of job-related well-being, this paper uses rich data that allow controlling for a range of employee, workplace and management

11 One could also argue that affective well-being measures, which are reflective of frequent experiences of positive and negative affects at work, are less expectation driven than measures of job satisfaction. 
practice related influences much more comprehensively than in any similar previous research. The paper also controls for geographic area and travel-to-work area unemployment and vacancy rates. Controlling for such geographic information will enable accounting exhaustively for observable factors behind firm and employee selection. That the paper accounts for workplace-level unobserved heterogeneity by employing alternative econometric models with different specifications make this study a more comprehensive one.

\section{Data and variables}

\subsection{Overview of the Data}

The data used in this paper come from the 2004 British Workplace Employment Relations Survey (WERS2004), which is one of the most authoritative sources of information on employment relations in Great Britain. It offers linked employer-employee data representative of all workplaces with five or more employees (Kersley et al. 2006). The survey covers a whole host of issues relating to both employers and employees, allowing the inclusion of an array of individual and workplace level attributes into the empirical analysis undertake. The estimation sub-sample used in this paper comprises of 17151 employees in 1441 workplaces. This is from the initial matched sample of 22451 employees in 1733 workplaces. The final sample is the result of excluding those with ( $i$ missing values in any of the job-related well-being measures used, (ii) missing values in any of the employee and workplace covariates including the disability diversity measure and (iii) keeping only workplaces with at least two responding employees.

\subsection{Definition of variables}

\subsubsection{Outcome (job-related well-being) variables}

The first important set of variables relates to WERS2004 survey questions that monitor employee job-related well-being. These come from two different sources. First, the employee survey monitored how satisfied employees are with eight different aspects of their job. The survey asked each employee to rate - on a five-point scale from 'very satisfied' to 'very dissatisfied' - how satisfied they were on: ( $\imath$ the sense of achievement they get from their work; (ii) the scope for using their own initiative; (iii) the amount of influence they have over their job; (iv) the training they receive; $(v)$ the amount of pay they receive; (vi) their job security; (vii) their work itself and (viii) their involvement in 
decision making. Secondly, the employee survey also monitored affective well-being measures. There are six questions that probe - on a five-point scale from 'all of the time' to 'Never' - how much of the time over the past few weeks employees felt (i) tense; (ii) calm; (iii) relaxed; (iv) worried; $(v)$ uneasy, and (vi) content. ${ }^{12}$ Each of these 14 variables is used as job-related well-being outcome measures. The appendix Tables A1 and A2 report descriptive statistics and correlation matrix of each of these 14 outcome variables.

\subsubsection{Disability Diversity and other control variables}

The disability diversity variable of interest to this paper is constructed based on the proportion of employees with disability at each workplace, which is monitored in the WERS2004 establishment survey. As detailed in the methodology section of the paper, disability diversity is defined as one minus the sum of squared proportions of disabled and non-disabled workers at workplaces. Other control variables used relate to employee demographic and human capital characteristics, employee occupation, skill requirement, industry of employment, geographic area and travel-to-work area unemployment and vacancy rates. Table A3 in the appendix provides descriptive statistics on all variables used in the empirical analysis.

\subsubsection{Workplace practice and policy summary variables}

Differentiating between a genuinely committed and strategic diversity policy accommodating disabled workers and cases where employers pay lip-service to diversity and equal opportunities but lack systematic action could be important. The WERS2004 data have extensive information on workplace management practice and policy, and some method of reducing this vast data is essential if arbitrary choices of items are to be avoided. To address these issues two approaches have been used in this paper. First, a sub-set of workforce management and policy variables that are thought to reflect genuine commitment, as opposed to paying lip-service, towards employees have been carefully selected. In particular, aspects of workplace management practices and policies that demonstrate commitment towards ( $($ ) equality, (ii) training and development of employees and (iii) provisions of flexibility have been chosen. Secondly, factor analysis has been used to construct three different summary measures reflecting equality, training and flexibility. ${ }^{13}$ The scores generated in this way are then used in the empirical analyses

\footnotetext{
${ }^{12}$ The order of responses signifying negative affects have been modified so that the six affective well-being measures become (i) NOT tense, (ii) calm, (iii) relaxed, (iv) NOT worried, (v) NOT uneasy and (vi) content. 13 The factor scores have been generated using SPSS
} 
conduct forming one specification of the models estimated. The idea behind using these summary scores is to explore whether genuine commitment in workplace policy and practice has any bearing regarding the links between workplace disability diversity and employee well-being. Appendix Tables A4 - A6 provide the list of workplace practice and policy variables used and Factor analysis related statistics.

\section{Empirical methodology}

There are important methodological considerations to be made in modelling subjective well-being measures. In this regard, two of the key issues are to do with the assumptions imposed on the meaning of satisfaction questions and the influence of unobservables (Ferreri-i-Carbonell and Frijters 2004). This paper follows the empirical economics tradition and assumes that responses to subjective well-being questions are comparable only ordinally. In other words, employees that give identical responses to a subjective well-being question will be assumed to derive similar levels of satisfaction on the particular aspect of their job. ${ }^{14}$ I therefore estimate ordinal probability models. The non-experimental nature of the study makes it essential that unobserved heterogeneity is accounted for. The level of workplace disability diversity observed or the particular workforce management practice and policy therein are less likely to represent random phenomena, given possible employer and employee selection. To the extent that there is such selection, addressing the issue of non-randomness becomes crucial to avoid the potentially biasing selection effects. This paper attempts to account for such potential biases by estimating random effects ordered logit models, which allow controlling for workplace-level unobserved heterogeneity. ${ }^{15}$

As stated in the data related discussion, the WERS2004 data is a linked data with some employees selected from the same workplace. This means some shared observed and unobserved attributes pertinent to the workplace. This violates the independence assumption that (ordinal) regression models assume (Hedeker and Gibbons 1994). This paper exploits the nested structure of the WERS2004 data to overcome violation of the independence assumption and employs the multilevel

\footnotetext{
${ }^{14}$ Nevertheless, it is important to stress the crucial role that employee expectation plays in determining such responses (to subjective well-being questions). I also test the cardinality assumption by estimating linear models that are commonly used in the psychology literature.

15 Since the data I use is cross-section data, I am only able to explicitly account for workplace level unobserved heterogeneity however.
} 
modelling framework. ${ }^{16}$ Estimating (workplace) fixed effects regression could have been an option. However, the cluster (or workplace) dummy variables would be correlated with important workplace characteristics including the disability diversity measure used. Moreover, previous research has shown that attempts to estimate FE models with the cluster effects treated as dummy variables gives rise to inconsistent estimates of the ordinal and regression coefficients, in addition to possible incidental parameter problem (Crouchley, 1995).

To estimate the random-effects ordered logit models the original five-scale responses have been converted into three-scale responses. The five-scale responses for the facets of job satisfaction are 'very satisfied', 'satisfied', 'neither satisfied nor dissatisfied', 'dissatisfied' and 'very dissatisfied', which are converted into the three-scales of satisfied, neither and dissatisfied by collapsing the first and the last two responses. Likewise, the five-scale responses for the affective well-being measures are 'all of the time', 'most of the time', 'some of the time', 'occasionally' and 'never', which are converted into occasionally/never, sometimes and always/mostly. Converting the original responses in this way avoids data thinning in the extreme scales, which makes model convergence difficult, particularly in random-effects ordered logit models. ${ }^{17}$

Previous studies have defined diversity as the percentage of women in gender focused studies. However, a percentage measure would not capture the link between diversity and various outcome measures of interest fully. In their recent study, Leonard and Levine (2006) elucidate the shortcomings of the percentage measure in that it increases linearly with the size of one group of interest even though such an increase would mean a reduction in the size of another. To be able to address this issue of nonlinearity, a disability diversity index, $D$, has been constructed in this paper where

\footnotetext{
16 The simplest way of addressing this is to use cluster option in a regression. However, this won't allow estimating a parameter measuring (shared) unobserved attributes. Neither would it allow testing the significance of such an influence.

17 The alternative models estimate are linear random effects model, which I estimate using the original fivescale responses, and random effects logit estimated on binary outcomes measures that assume 1 if satisfied or very satisfied and 0 otherwise (or 1 if always/mostly and 0 othersise). The linear random effects model enables us to check whether using the cardinality assumption makes much difference to my empirical findings. Also, it is argued that when the number of categories is large ( 5 or more) it may be possible to approximate the distribution by a normal distribution and applying multilevel linear models (Snijders and Bosker, 2004). All three models are estimated in STATA using STATA's multilevel facility and GLLAMM. The multi-level analytical designs are best suited to the nested data I have. They are regarded as more attractive and advocated, for example, by Jackson et al. (2003).
} 
$D=1-\sum_{i} S_{k}^{2}$ where $S$ represents the shares of disabled and non-disabled employees at a workplace and $i=1,2 .^{18}$

The random-effects ordered logit model can be formulate as a threshold model with observed ordinal well-being responses $w_{i j}$ of employee $i$ in workplace $j$ generated from the latent continuous responses $w_{i j}^{*}$ as

$$
w_{i j}=\left\{\begin{array}{ccc}
1 & \text { if } & w_{i j}^{*} \leq \kappa_{1} \\
2 & \text { if } & \kappa_{1}<w_{i j}^{*} \leq \kappa_{2} \\
\vdots & & \vdots \\
S & \text { if } & \kappa_{S-1}<w_{i j}^{*}
\end{array}\right.
$$

The well-being response variable $w_{i j}$ could be assumed to take values $s$ with probability $p_{i j}(s)=\operatorname{Pr}\left(w_{i j}=s\right)$ and cumulative response probabilities $P_{i j}(s)=\operatorname{Pr}\left(w_{i j} \leq s\right)=\sum_{r=1}^{s} p_{i j}(r), \quad r=1, \ldots, s-1$, for the $s$ categories of ordinal outcome of $w_{i j}$. The cumulative probabilities can be given by $P_{i j}(s)=F\left(\kappa_{s}-\eta_{i j}\right), s=1, \ldots, S-1$, where $F$ is the cumulative density function of the model residuals, $\varepsilon_{i j}$ that can also be expressed as $P_{i j}(s)=R\left[P_{i j}(s)\right]=\kappa_{s}-\eta_{i j}, \quad s=1, \ldots, S-1$, where $R=F^{-1}$ is the link function. Assuming the distribution of the model residuals for the latent well-being response, $w_{i j}^{*}$, to be logistic, the cumulative probabilities can be given by

$$
P_{i j}(s)=\operatorname{Pr}\left(\varepsilon_{i j} \leq \kappa_{s}-\eta_{i j}\right)=\frac{\exp \left(\kappa_{s}-\eta_{i j}\right)}{1+\exp \left(\kappa_{s}-\eta_{i j}\right)}
$$

or, alternatively as

$$
\log \left[\frac{P_{i j}(s)}{1-P_{i j}(s)}\right]=\log \left[\frac{\operatorname{Pr}\left(w_{i j} \leq s\right)}{1-\operatorname{Pr}\left(w_{i j} \leq s\right)}\right]=\kappa_{s}-\eta_{i j} \quad s=1, \ldots, S-1
$$

\footnotetext{
${ }^{18}$ The diversity index is also known as one minus the Herfindahl Index and Blau's Index and assumes a theoretical value ranging, in my case, from a minimum of 0 , signifying perfect homogeneity, to a maximum of 0.5 , signifying perfect heterogeneity.
} 
where $\kappa_{c}$ is the threshold parameter for categories $s=1, \ldots, S-1$ and

$\eta_{i j}=\beta_{o j}+\sum_{l=1}^{L} \beta_{l j} X_{l i j}$. The general model can thus be given by

$$
\log \left[\frac{\operatorname{Pr}\left(w_{i j} \leq s\right)}{1-\operatorname{Pr}\left(w_{i j} \leq s\right)}\right]=\kappa_{s}-\left(\beta_{o j}+\sum_{l=1}^{L} \beta_{l j} X_{l i j}\right)
$$

The vector $X$ represents $L$ covariates that include the diversity index as well as the whole array of covariates relating to employees, their workplaces and geographic location. Since the regression coefficients in equation (5) do not carry the subscript $s$, they do not vary across the ordinal categories. Crucially, the intercept term $\beta_{0 j}$ in equation (5) has a workplace random component so that $\beta_{0 j}=\beta_{00}+\xi_{0 j}$, where $\beta_{00}$ is the mean intercept and $\xi_{0 j}$ is the deviation of the establishment specific intercept $\beta_{0 j}$ from the mean. I make several important assumptions in this set up including: independence across the $j$ workplaces (level-2 units), normally distributed employee error terms $\left(\varepsilon_{i j} \mid x_{i j} \sim N(0, \theta)\right)$ with no correlation between error terms associated with any two different employees within a workplace, i.e. $\left(\operatorname{Cov}\left(\varepsilon_{i j}, \varepsilon_{i^{\prime} j}\right)=0\right.$ for $\left.i \neq i^{\prime}\right)$ and workplace level variations that are distributed normally and uncorrelated with individual/employee error terms, i.e. $\xi_{0 j} \mid x_{i j} \sim N(0, \psi) \& \operatorname{Cov}\left(\xi_{0 j}, \varepsilon_{i j}\right)=0$, where $\theta \equiv \operatorname{Var}\left(\varepsilon_{i j}\right) \& \psi \equiv \operatorname{Var}\left(\xi_{0 j}\right)$ (Hedeker and Gibbons 1994, Crouchley 1995, Snijders and Bosker 2004, Rabe-Hesketh and Skrondal 2008)

\section{Empirical results and discussion}

Estimation results from the random-effects logit equations relating to the fourteen job-related well-being outcome measures are reported in Tables 1 through 14, where the first eight Tables relate to the facets of job satisfaction while the remaining six Tables relate to measures of affective well-being. ${ }^{19}$ In each case, I estimate three different specifications of the well-being equations to be able to check for robustness of estimation results.

\footnotetext{
19 The results I report in these Tables are specific to the diversity related coefficient estimates. Corresponding Tables with the full set of coefficient estimates and estimation results from the alternative linear random effects and random effects logit models are available on request. All reported estimates are un-weighted..
} 
A descriptive statistics of the fourteen job-related well-being outcomes and a correlation matrix depicting the correlation structure among these outcome measures are given in Appendix Tables A1 and A2. The correlation matrix shows that affective wellbeing measures are positively correlated with all facets of job satisfaction. This correlation is stronger among the affective well-being measures themselves, but there are also noticeable correlations between the affective well-being measures and the facet satisfaction measures relating, for example, to the 'work itself, 'sense of achievement', 'amount of influence on the job' and 'scope for using own initiative' in particular. Of the facet satisfaction measures, satisfaction with "the work itself" has the strongest of correlations with all other measures of job-related well-being, including the measures of affective well-being. This is in line with previous findings where satisfaction with the nature of work undertaken is found to be particularly closely associated with other facetspecific satisfaction and with overall job satisfaction (Warr 1999).

Figure A1 in the Appendix shows a plot of the workplace disability diversity index computed. It shows a huge spike at 0 and most values of the index fall between 0 and 0.1 . This suggests that some 55 per cent of workplaces are homogeneous in terms of disability, and that most of the remaining workplaces depart from homogeneity only marginally. It is important to note however that there are also some workplaces that have near or full heterogeneity in terms of disability.

Appendix Table A3 reports descriptive statistics on the regressors used in the modelling. These include both employee and workplace characteristics. Accordingly, women constitute slightly more than 50 per cent of employees in the estimation sample while those that are 50 or over make up a quarter. Some 68 per cent of employees are married and only 5 per cent are non-white. A sample characteristic of particular importance, the proportion of employees with disability, indicates that the disabled make up 12 per cent of employees in the final sample. Nearly 60 per cent of employees report that their skills do not match the skills requirements of their job. Most employees (92\%) are on permanent contract and 79 per cent of employees are employed full-time. Some 35 per cent of employees in the sample are trade union members. In terms of workplace characteristics, some 70 per cent of workplaces are private establishments. The proportion of workplaces that are sole establishments stands at 22 per cent, indicating that most workplaces are part of a multi-establishment setup. Also, most workplaces $(82 \%)$ are establishments based in urban areas. 
The reported descriptive statistics also includes the three summary measures of workplace practice/policy variables representing provisions of equality, training and flexibility at the workplace. As stated in the data section, careful selection of variables that are likely to demonstrate employers' commitment towards their employees has been made. The idea here is that if the employer is committed to these aspects of employee development and hence scoring high on the summary measures, then this may remove the potentially negative relationship between disability diversity and employee job-related well-being. Appendix Tables A4 to A6 report some outputs from Factor Analysis that generated the summary scores. Table A4 in the Appendix shows the Kaiser-Meyer-Olkin (KMO) measure of sampling adequacy and Bartlett's test of sphericity. The KMO statistic of 0.91 suggests that patterns of correlations among the variables selected are relatively compact and that factor analysis is highly likely to yield distinct and reliable factors. The Bartlett's test statistic means that the null hypothesis that the original correlation matrix is an identity matrix is rejected decisively.

I estimate three different specifications of the random-effects ordered logit model for each of the fourteen job-related well-being outcomes. The first specification seeks to establish the link between the main disability diversity variable and employee job-related well-being, controlling for only employee-level characteristics. The second specification makes a further control for establishment-level characteristics, including labour market characteristics in the establishment's locality. The third specification controls for influences relating to workplace policy and practice by incorporating summary scores generated from Factor Analysis into the models estimated. ${ }^{20}$

As could be seen from Tables 1 to 14, the direction of the links between disability diversity and all but one of the fourteen measures of employee well-being are negative and consistent across the three specifications. In terms of statistical significance, however, only seven of the fourteen equations produce at least one negative and statistically significant association. The sub-group based estimation results for disabled and non-disabled employees reported in Tables $1 \mathrm{a}$ to $14 \mathrm{a}$ and Tables $1 \mathrm{~b}$ to $14 \mathrm{~b}$, respectively, show some differences in the direction and significance of the links between disability diversity and employee well-being. Accordingly, twelve of the fourteen equations estimated for disabled employees indicate positive association between disability diversity and employee well-being although none of these (or the remaining two coefficients with negative coefficients) are statistically significant. In contrast, thirteen of

\footnotetext{
${ }^{20}$ Although not report in the current paper, a fourth specification that includes an interaction of the equality summary measure and the disability diversity measure has been estimated.
} 
the fourteen equations estimated for non-disabled employees indicate a negative association between disability diversity and employee well-being and seven of these are found to be statistically significant.

In terms, thus, of the hypotheses put forward in Section 2.1, the discussions in the preceding paragraphs indicate that:

(i) the estimation results in Tables 1 to 14 lend sufficient, though by no means complete, support that disability diversity leads to lower employee well-being,

(ii) the sub-group based results also provide support for the second hypothesis in that the lower employee well-being in $(\imath)$ are all associated with non-disabled employees.

I also undertake further empirical analysis to test the remaining two hypotheses. To be able to test the third hypothesis I constructed discrete measures of workplace disability diversity that assume three values. The first discrete measure assumes a value of 1 if the workplace has a disability diversity value that is less than or equal to the mean value of the workplace disability diversity index for all workplaces and 0 otherwise. The second discrete measure assumes a value of 1 if the workplace has a workplace disability diversity value that is above the mean value for all workplaces but that is below the $90^{\text {th }}$ percentile value of the disability diversity index for all workplaces and 0 otherwise. The third discrete measure assumes a value of 1 if the workplace has a disability diversity value greater than or equal to the $90^{\text {th }}$ percentile value of the workplace disability diversity index for all workplaces and 0 otherwise. I re-estimate all main and sub-group based well-being equations using the discrete measures of workplace disability diversity.

Tables $2 \mathrm{c}, 3 \mathrm{c}, 6 \mathrm{c}, 10 \mathrm{c}$ and $13 \mathrm{c}$ report estimation results for the non-disabled sub-sample for which the preceding analysis indicated robust negative and statistically significant link between workplace disability diversity and employee well-being. These results indicate that both in terms of magnitude and statistical significance higher levels of workplace disability diversity are associated with lower levels of well-being for nondisabled workers. Thus:

(iii) the results reported in Tables 2c, 3c, 6c, 10c and 13c lend support to the $3^{\text {rd }}$ hypothesis, which relates to disabled-group size related effect

Support for the $4^{\text {th }}$ hypothesis comes from two sources. First, the $3^{\text {rd }}$ specification in each of the well-being equations we estimated includes a variable that captures the quality of workplace equality measure in place at the workplace. If the 
negative association between the workplace disability diversity measure and a particular well-being measure is not removed as a result the inclusion of the equality variable, then this amounts to some support to bypothesis $4 b$. As well as this, I estimated a series of wellbeing equations that include an interaction term of the workplace disability diversity variable and the equality variable. However, I do not find any statistically significant effect for such an interaction term.

\section{Summary and Conclusion}

This paper attempted to establish empirically whether there is a link between workplace disability diversity and employee job-related well-being using the WERS2004 data. It uses an index of workplace disability diversity and fourteen different measures of employee job-related well-being. These well-being measures include: ( $\imath$ eight measures on facets of satisfaction and (ii) six measures of affective well-being. The paper made extensive review of the relevant theoretical literature and sat up four testable hypotheses regarding: ( $($ ) links between workplace disability diversity and each of the job-related wellbeing measures, (ii) whether there are differences between disabled and non-disabled employees regarding these links, (iii) if the relationship in (i) changes with the degree of workplace disability diversity and (iv) whether workplace equality policy influences the links observed.

The paper employs random-effects ordered logit models to carry out the empirical analysis and assumes that responses to subjective well-being measures are comparable (only) ordinally. It also accounts for unobserved workplace-level heterogeneity. The later is achieved by exploiting the nested structure of the WERS2004 data. As well as the random-effects ordered logit models, alternative equations involving linear random-effects models have been estimated to test whether the cardinality assumption would make a difference and this is not the case. Alternative specifications of the well-being equations have been estimated and the results obtained are mostly robust.

The empirical findings reported lend some support to each of the testable hypothesis I have sat up on the basis of theory. Accordingly: ( $\imath$ ) workplace disability diversity is associated with lower employee job-related well-being in several of the wellbeing equations estimated, (ii) it is non-disabled employees that bear the reductions in well-being, (iii) the effect in (ii) is found to increase with the size of the disabled group, and (iv) equality policy at the workplace is not found to ameliorate the adverse effects of well-being associated with workplace disability diversity. 


\section{A. Disability diversity $\&$ facets of job satisfaction ${ }^{21}$}

Table 1: Disability diversity and satisfaction with the sense of achievement from work, all employees

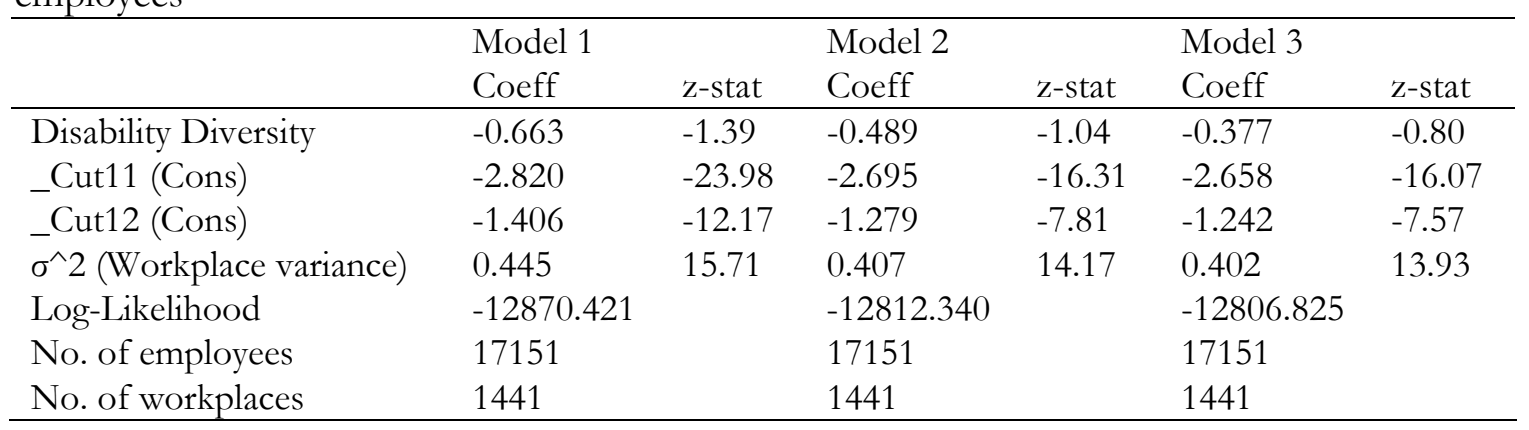

Table 1a: Disability diversity and satisfaction with the sense of achievement from work, disabled employees

\begin{tabular}{lllllll}
\hline & Model 1 & & Model 2 & & Model 3 & \\
& Coeff & z-stat & Coeff & z-stat & Coeff & z-stat \\
\hline Disability Diversity & -0.004 & 0.00 & 0.192 & 0.22 & 0.256 & 0.29 \\
_Cut11 (Cons) & -3.100 & -8.53 & -3.251 & -7.02 & -3.239 & -6.98 \\
_Cut12 (Cons) & -1.751 & -4.94 & -1.901 & -4.16 & -1.891 & -4.13 \\
$\sigma^{\wedge}$ (Workplace variance) & 0.544 & 4.17 & 0.445 & 2.95 & 0.421 & 2.66 \\
Log-Likelihood & -1632.496 & & -1612.891 & & -1611.299 & \\
No. of employees & 2009 & & 2009 & & 2009 & \\
No. of workplaces & 1007 & & 1007 & & 1007 & \\
\hline
\end{tabular}

Table 1b: Disability diversity and satisfaction with the sense of achievement from work, non-disabled employees

\begin{tabular}{|c|c|c|c|c|c|c|}
\hline & Model 1 & & Model 2 & & Model 3 & \\
\hline & Coeff & z-stat & Coeff & z-stat & Coeff & z-stat \\
\hline Disability Diversity & -0.837 & -1.58 & -0.702 & -1.33 & -0.580 & -1.09 \\
\hline _Cut11 (Cons) & -2.787 & -22.35 & -2.627 & -15.04 & -2.587 & -14.80 \\
\hline _Cut12 (Cons) & -1.355 & -11.06 & -1.192 & -6.89 & -1.152 & -6.65 \\
\hline$\sigma^{\wedge} 2$ (Workplace variance) & 0.442 & 14.18 & 0.407 & 12.87 & 0.402 & 12.63 \\
\hline Log-Likelihood & -11220.034 & & -11168.757 & & -11163.756 & \\
\hline No. of employees & 15142 & & 15142 & & 15142 & \\
\hline No. of workplaces & 1440 & & 1440 & & 1440 & \\
\hline
\end{tabular}

${ }^{21}$ All are estimates from random effects ordered logit models. Model 1 controls for employee characteristics only, Model 2 controls for both employee and employer characteristics while Model 3 includes further controls on summary measures of workplace policy and practices. Descriptive statistics of all controls is provided in Table 3A in the Appendix. Estimation conducted using GLLAMM. Full estimation results can be provided on request. 
Table 2: Disability diversity and satisfaction with the scope for using own initiative, all employees

\begin{tabular}{lllllll}
\hline & Model 1 & & Model 2 & & Model 3 & \\
& Coeff & z-stat & Coeff & z-stat & Coeff & z-stat \\
\hline Disability Diversity & -1.078 & -2.31 & -0.992 & -2.14 & -0.889 & -1.91 \\
_Cut11 (Cons) & -3.007 & -25.15 & -2.967 & -17.76 & -2.960 & -17.67 \\
_Cut12 (Cons) & -1.669 & -14.20 & -1.627 & -9.83 & -1.620 & -9.76 \\
$\sigma^{\wedge}$ (Workplace variance) & 0.431 & 14.74 & 0.403 & 13.60 & 0.401 & 13.52 \\
Log-Likelihood & -12594.731 & & -12552.513 & & -12549.691 & \\
No. of employees & 17151 & & 17151 & & 17151 & \\
No. of workplaces & 1441 & & 1441 & & 1441 & \\
\hline
\end{tabular}

Table 2a: Disability diversity and satisfaction with the scope for using own initiative, disabled employees

\begin{tabular}{lllllll}
\hline & Model 1 & & Model 2 & & Model 3 & \\
& Coeff & z-stat & Coeff & z-stat & Coeff & z-stat \\
\hline Disability Diversity & 0.030 & 0.03 & 0.166 & 0.19 & 0.207 & 0.24 \\
_Cut11 (Cons) & -3.545 & -9.60 & -3.755 & -7.96 & -3.742 & -7.89 \\
_Cut12 (Cons) & -2.377 & -6.60 & -2.590 & -5.59 & -2.576 & -5.52 \\
$\sigma^{\wedge}$ 2 (Workplace variance) & 0.519 & 3.80 & 0.424 & 2.73 & 0.408 & 2.55 \\
Log-Likelihood & -1621.818 & & -1606.979 & & -1604.237 & \\
No. of employees & 2009 & & 2009 & & 2009 & \\
No. of workplaces & 1007 & & 1007 & & 1007 & \\
\hline
\end{tabular}

Table 2b: Disability diversity and satisfaction with the scope for using own initiative, non-disabled employees

\begin{tabular}{lllllll}
\hline & Model 1 & & Model 2 & & Model 3 & \\
& Coeff & z-stat & Coeff & z-stat & Coeff & z-stat \\
\hline Disability Diversity & -1.426 & -2.75 & -1.384 & -2.67 & -1.279 & -2.45 \\
-Cut11 (Cons) & -2.947 & -23.20 & -2.866 & -16.22 & -2.860 & -16.14 \\
_Cut12 (Cons) & -1.575 & -12.62 & -1.492 & -8.52 & -1.485 & -8.46 \\
$\sigma^{\wedge}$ 2 (Workplace variance) & 0.432 & 13.50 & 0.406 & 12.54 & 0.405 & 12.49 \\
Log-Likelihood & -10958.187 & & -10922.117 & & -10920.245 & \\
No. of employees & 15142 & & 15142 & & 15142 & \\
No. of workplaces & 1440 & & 1440 & & 1440 & \\
\hline
\end{tabular}

Table 3: Disability diversity and satisfaction with the amount of influence over the job, all employees

\begin{tabular}{lllllll}
\hline & Model 1 & & Model 2 & & Model 3 & \\
& Coeff & z-stat & Coeff & z-stat & Coeff & z-stat \\
\hline Disability Diversity & -1.168 & -2.67 & -1.076 & -2.50 & -0.933 & -2.16 \\
-Cut11 (Cons) & -2.780 & -26.38 & -2.658 & -17.92 & -2.646 & -17.81 \\
_Cut12 (Cons) & -1.167 & -11.29 & -1.043 & -7.10 & -1.031 & -7.00 \\
$\sigma^{\wedge}$ (Workplace variance) & 0.429 & 17.16 & 0.390 & 15.43 & 0.387 & 15.29 \\
Log-Likelihood & -15595.544 & & -15538.883 & & -15532.868 & \\
No. of employees & 17151 & & 17151 & & 17151 & \\
No. of workplaces & 1441 & & 1441 & & 1441 & \\
\hline
\end{tabular}


Table 3a: Disability diversity and satisfaction with the amount of influence over the job, disabled employees

\begin{tabular}{lllllll}
\hline & Model 1 & & Model 2 & & Model 3 & \\
& Coeff & z-stat & Coeff & z-stat & Coeff & z-stat \\
\hline Disability Diversity & 0.284 & 0.34 & 0.411 & 0.49 & 0.513 & 0.62 \\
_Cut11 (Cons) & -3.157 & -9.75 & -3.246 & -7.87 & -3.227 & -7.78 \\
CCut12 (Cons) & -1.640 & -5.24 & -1.735 & -4.29 & -1.717 & -4.21 \\
$\sigma^{\wedge} 2$ (Workplace variance) & 0.526 & 4.35 & 0.438 & 3.22 & 0.417 & 2.93 \\
Log-Likelihood & -1945.569 & & -1931.510 & & -1927.306 & \\
No. of employees & 2009 & & 2009 & & 2009 & \\
No. of workplaces & 1007 & & 1007 & & 1007 & \\
\hline
\end{tabular}

Table 3b: Disability diversity and satisfaction with the amount of influence over the job, non-disabled employees

\begin{tabular}{lllllll}
\hline & Model 1 & & Model 2 & & Model 3 & \\
& Coeff & z-stat & Coeff & z-stat & Coeff & z-stat \\
\hline Disability Diversity & -1.604 & -3.32 & -1.518 & -3.19 & -1.374 & -2.87 \\
-Cut11 (Cons) & -2.735 & -24.41 & -2.581 & -16.44 & -2.569 & -16.33 \\
_Cut12 (Cons) & -1.097 & -9.98 & -0.942 & -6.06 & -0.930 & -5.96 \\
$\sigma^{\wedge}$ (Workplace variance) & 0.434 & 15.95 & 0.396 & 14.33 & 0.394 & 14.25 \\
Log-Likelihood & -13633.766 & & -13582.449 & & -13578.331 & \\
No. of employees & 15142 & & 15142 & & 15142 & \\
No. of workplaces & 1440 & & 1440 & & 1440 & \\
\hline
\end{tabular}

Table 4: Disability diversity and satisfaction with job training received, all employees

\begin{tabular}{lllllll}
\hline & Model 1 & Model 2 & Model 3 & \\
& Coeff & z-stat & Coeff & z-stat & Coeff & z-stat \\
\hline Disability Diversity & 0.368 & 0.73 & 0.262 & 0.53 & 0.237 & 0.47 \\
_Cut11 (Cons) & -1.329 & -13.21 & -1.223 & -7.80 & -1.208 & -7.71 \\
_Cut12 (Cons) & 0.023 & 0.23 & 0.131 & 0.83 & 0.145 & 0.93 \\
$\sigma^{\wedge}$ 2 (Workplace variance) & 0.607 & 24.96 & 0.578 & 24.26 & 0.571 & 23.96 \\
Log-Likelihood & -17052.476 & & -17000.692 & & -16993.963 & \\
No. of employees & 17151 & & 17151 & & 17151 & \\
No. of workplaces & 1441 & & 1441 & & 1441 & \\
\hline
\end{tabular}

Table 4a: Disability diversity and satisfaction with job training received, disabled employees

\begin{tabular}{lllllll}
\hline & Model 1 & & Model 2 & & Model 3 & \\
& Coeff & z-stat & Coeff & z-stat & Coeff & z-stat \\
\hline Disability Diversity & 1.040 & 1.21 & 1.240 & 1.46 & 1.151 & 1.36 \\
_Cut11 (Cons) & -1.426 & -4.77 & -1.805 & -4.51 & -1.737 & -4.32 \\
CCut12 (Cons) & -0.059 & -0.20 & -0.436 & -1.10 & -0.367 & -0.92 \\
$\sigma^{\wedge} 2$ (Workplace variance) & 0.587 & 5.46 & 0.517 & 4.52 & 0.498 & 4.23 \\
Log-Likelihood & -2039.252 & & -2019.848 & & -2015.494 & \\
No. of employees & 2009 & & 2009 & & 2009 & \\
No. of workplaces & 1007 & & 1007 & & 1007 & \\
\hline
\end{tabular}


Table 4b: Disability diversity and satisfaction with job training received, non-disabled employees

\begin{tabular}{|c|c|c|c|c|c|c|}
\hline & Model 1 & & Model 2 & & Model 3 & \\
\hline & Coeff & z-stat & Coeff & z-stat & Coeff & $z$-stat \\
\hline Disability Diversity & 0.237 & 0.43 & 0.065 & 0.12 & 0.063 & 0.12 \\
\hline _Cut11 (Cons) & -1.315 & -12.33 & -1.165 & -7.10 & -1.150 & -7.01 \\
\hline _Cut12 (Cons) & 0.038 & 0.36 & 0.189 & 1.15 & 0.204 & 1.25 \\
\hline$\sigma^{\wedge} 2$ (Workplace variance) & 0.608 & 23.50 & 0.581 & 22.85 & 0.576 & 22.60 \\
\hline Log-Likelihood & -15029.665 & & -14984.600 & & -14978.969 & \\
\hline No. of employees & 15142 & & 15142 & & 15142 & \\
\hline No. of workplaces & 1440 & & 1440 & & 1440 & \\
\hline
\end{tabular}

Table 5: Disability diversity and satisfaction with the amount of pay received, all employees

\begin{tabular}{lllllll}
\hline & Model 1 & & Model 2 & & Model 3 & \\
& Coeff & z-stat & Coeff & z-stat & Coeff & z-stat \\
\hline Disability Diversity & -0.623 & -1.23 & -0.362 & -0.72 & -0.281 & -0.56 \\
_Cut11 (Cons) & -1.712 & -17.14 & -1.835 & -11.69 & -1.830 & -11.63 \\
_Cut12 (Cons) & -0.599 & -6.04 & -0.721 & -4.61 & -0.715 & -4.56 \\
$\sigma^{\wedge}$ 2 (Workplace variance) & 0.617 & 25.96 & 0.595 & 25.42 & 0.594 & 25.38 \\
Log-Likelihood & -17774.147 & & -17734.232 & & -17732.764 & \\
No. of employees & 17151 & & 17151 & & 17151 & \\
No. of workplaces & 1441 & & 1441 & & 1441 & \\
\hline
\end{tabular}

Table 5a: Disability diversity and satisfaction with the amount of pay received, disabled employees

\begin{tabular}{lllllll}
\hline & Model 1 & & Model 2 & & Model 3 & \\
& Coeff & z-stat & Coeff & z-stat & Coeff & z-stat \\
\hline Disability Diversity & -0.422 & -0.57 & -0.016 & -0.02 & 0.088 & 0.12 \\
-Cut11 (Cons) & -1.796 & -6.26 & -1.552 & -4.19 & -1.573 & -4.21 \\
_Cut12 (Cons) & -0.751 & -2.65 & -0.512 & -1.39 & -0.532 & -1.43 \\
$\sigma^{\wedge}$ 2 (Workplace variance) & 0.293 & 1.65 & -0.138 & -0.38 & 0.118 & 0.28 \\
Log-Likelihood & -2062.792 & & -2051.400 & & -2049.272 & \\
No. of employees & 2009 & & 2009 & & 2009 & \\
No. of workplaces & 1007 & & 1007 & & 1007 & \\
\hline
\end{tabular}

Table 5b: Disability diversity and satisfaction with the amount of pay received, nondisabled employees

\begin{tabular}{lllllll}
\hline & Model 1 & & Model 2 & & Model 3 & \\
& Coeff & z-stat & Coeff & z-stat & Coeff & z-stat \\
\hline Disability Diversity & -0.632 & -1.15 & -0.397 & -0.73 & -0.328 & -0.60 \\
_Cut11 (Cons) & -1.687 & -15.95 & -1.857 & -11.32 & -1.854 & -11.26 \\
_Cut12 (Cons) & -0.569 & -5.43 & -0.738 & -4.52 & -0.735 & -4.48 \\
$\sigma^{\wedge}$ (Workplace variance) & 0.623 & 24.61 & 0.600 & 24.03 & 0.599 & 24.01 \\
Log-Likelihood & -15735.620 & & -15696.071 & & -15695.179 & \\
No. of employees & 15142 & & 15142 & & 15142 & \\
No. of workplaces & 1440 & & 1440 & & 1440 & \\
\hline
\end{tabular}


Table 6: Disability diversity and satisfaction with job security, all employees

\begin{tabular}{lllllll}
\hline & Model 1 & & Model 2 & & Model 3 & \\
& Coeff & z-stat & Coeff & z-stat & Coeff & z-stat \\
\hline Disability Diversity & -1.607 & -2.36 & -1.472 & -2.26 & -1.334 & -2.03 \\
_Cut11 (Cons) & -1.316 & -11.74 & -0.938 & -4.82 & -0.936 & -4.79 \\
_Cut12 (Cons) & 0.123 & 1.10 & 0.502 & 2.58 & 0.504 & 2.59 \\
$\sigma^{\wedge} 2$ (Workplace variance) & 0.939 & 31.62 & 0.865 & 30.46 & 0.865 & 30.46 \\
Log-Likelihood & -14425.452 & & -14342.434 & & -14339.975 & \\
No. of employees & 17151 & & 17151 & & 17151 & \\
No. of workplaces & 1441 & & 1441 & & 1441 & \\
\hline
\end{tabular}

Table 6a: Disability diversity and satisfaction with job security, disabled employees

\begin{tabular}{lllllll}
\hline & Model 1 & & Model 2 & & Model 3 & \\
& Coeff & z-stat & Coeff & z-stat & Coeff & z-stat \\
\hline Disability Diversity & 0.332 & 0.33 & 0.363 & 0.36 & 0.484 & 0.48 \\
-Cut11 (Cons) & -0.851 & -2.67 & -0.653 & -1.49 & -0.707 & -1.60 \\
_Cut12 (Cons) & 0.399 & 1.25 & 0.598 & 1.37 & 0.546 & 1.24 \\
$\sigma^{\wedge}$ 2 (Workplace variance) & 0.802 & 7.74 & 0.754 & 7.15 & 0.754 & 7.15 \\
Log-Likelihood & -1844.372 & & -1830.035 & & -1828.477 & \\
No. of employees & 2009 & & 2009 & & 2009 & \\
No. of workplaces & 1007 & & 1007 & & 1007 & \\
\hline
\end{tabular}

Table 6b: Disability diversity and satisfaction with job security, non-disabled employees

\begin{tabular}{lllllll}
\hline & Model 1 & & Model 2 & \multicolumn{3}{c}{ Model 3 } \\
& Coeff & z-stat & Coeff & z-stat & Coeff & z-stat \\
\hline Disability Diversity & -2.114 & -2.88 & -2.000 & -2.84 & -1.879 & -2.65 \\
_Cut11 (Cons) & -1.337 & -11.17 & -0.952 & -4.64 & -0.948 & -4.60 \\
_Cut12 (Cons) & 0.138 & 1.16 & 0.525 & 2.56 & 0.529 & 2.57 \\
$\sigma^{\wedge} 2$ (Workplace variance) & 0.974 & 30.59 & 0.894 & 29.37 & 0.894 & 29.37 \\
Log-Likelihood & -12618.960 & & -12535.248 & & -12533.662 & \\
No. of employees & 15142 & & 15142 & & 15142 & \\
No. of workplaces & 1440 & & 1440 & & 1440 & \\
\hline
\end{tabular}

Table 7: Disability diversity and satisfaction with the work itself, all employees

\begin{tabular}{lllllll}
\hline & Model 1 & Model 2 & \multicolumn{3}{c}{ Model 3 } \\
& Coeff & z-stat & Coeff & z-stat & Coeff & z-stat \\
\hline Disability Diversity & -0.701 & -1.45 & -0.552 & -1.15 & -0.447 & -0.93 \\
-Cut11 (Cons) & -2.932 & -24.52 & -2.674 & -15.90 & -2.651 & -15.73 \\
_Cut12 (Cons) & -1.513 & -12.89 & -1.253 & -7.52 & -1.230 & -7.36 \\
$\sigma^{\wedge}$ (Workplace variance) & 0.464 & 16.34 & 0.425 & 14.74 & 0.422 & 14.64 \\
Log-Likelihood & -12515.534 & & -12463.472 & & -12459.674 & \\
No. of employees & 17151 & & 17151 & & 17151 & \\
No. of workplaces & 1441 & & 1441 & & 1441 & \\
\hline
\end{tabular}


Table 7a: Disability diversity and satisfaction with the work itself, disabled employees

\begin{tabular}{lllllll}
\hline & Model 1 & & Model 2 & \multicolumn{3}{c}{ Model 3 } \\
& Coeff & z-stat & Coeff & z-stat & Coeff & z-stat \\
\hline Disability Diversity & -0.082 & -0.09 & 0.189 & 0.23 & 0.211 & 0.25 \\
-Cut11 (Cons) & -2.918 & -8.21 & -3.202 & -7.06 & -3.214 & -7.04 \\
_Cut12 (Cons) & -1.514 & -4.36 & -1.805 & -4.03 & -1.818 & -4.03 \\
$\sigma^{\wedge}$ 2 (Workplace variance) & 0.451 & 2.95 & 0.276 & 1.21 & 0.274 & 1.19 \\
Log-Likelihood & -1591.084 & & -1572.284 & & -1572.184 & \\
No. of employees & 2009 & & 2009 & & 2009 & \\
No. of workplaces & 1007 & & 1007 & & 1007 & \\
\hline
\end{tabular}

Table 7b: Disability diversity and satisfaction with the work itself, non-disabled employees

\begin{tabular}{lllllll}
\hline & Model 1 & & Model 2 & & Model 3 & \\
& Coeff & z-stat & Coeff & z-stat & Coeff & z-stat \\
\hline Disability Diversity & -0.801 & -1.48 & -0.688 & -1.29 & -0.573 & -1.06 \\
_Cut11 (Cons) & -2.918 & -22.98 & -2.591 & -14.60 & -2.565 & -14.42 \\
_Cut12 (Cons) & -1.493 & -11.99 & -1.165 & -6.62 & -1.139 & -6.46 \\
$\sigma^{\wedge}$ (Workplace variance) & 0.464 & 14.99 & 0.427 & 13.54 & 0.424 & 13.39 \\
Log-Likelihood & -10918.796 & & -10873.121 & & -10869.061 & \\
No. of employees & 15142 & & 15142 & & 15142 & \\
No. of workplaces & 1440 & & 1440 & & 1440 & \\
\hline
\end{tabular}

Table 8: Disability diversity \& satisfaction with involvement in decision-making, all employees

\begin{tabular}{|c|c|c|c|c|c|c|}
\hline & \multicolumn{2}{|l|}{ Model 1} & \multicolumn{2}{|l|}{ Model 2} & \multicolumn{2}{|l|}{ Model 3} \\
\hline & Coeff & z-stat & Coeff & z-stat & Coeff & z-stat \\
\hline Disability Diversity & -0.851 & -1.74 & -0.625 & -1.30 & -0.435 & -0.91 \\
\hline _Cut11 (Cons) & -2.694 & -26.51 & -2.711 & -17.66 & -2.667 & -17.40 \\
\hline _Cut12 (Cons) & -0.793 & -7.96 & -0.806 & -5.30 & -0.762 & -5.02 \\
\hline$\sigma^{\wedge} 2$ (Workplace variance) & 0.579 & 23.99 & 0.540 & 22.93 & 0.533 & 22.64 \\
\hline Log-Likelihood & -17463.790 & & -17397.624 & & -17386.054 & \\
\hline No. of employees & 17151 & & 17151 & & 17151 & \\
\hline No. of workplaces & 1441 & & 1441 & & 1441 & \\
\hline
\end{tabular}

Table 8a: Disability diversity \& satisfaction with involvement in decision-making, disabled employees

\begin{tabular}{lllllll}
\hline & Model 1 & & Model 2 & & Model 3 & \\
& Coeff & z-stat & Coeff & z-stat & Coeff & z-stat \\
\hline Disability Diversity & 0.439 & 0.51 & 0.542 & 0.65 & 0.655 & 0.79 \\
_Cut11 (Cons) & -3.089 & -9.86 & -3.388 & -8.31 & -3.425 & -8.38 \\
CCut12 (Cons) & -1.284 & -4.26 & -1.588 & -4.00 & -1.627 & -4.09 \\
$\sigma^{\wedge} 2$ (Workplace variance) & 0.613 & 5.81 & 0.519 & 4.48 & 0.497 & 4.18 \\
Log-Likelihood & -2086.126 & & -2066.541 & & -2062.580 & \\
No. of employees & 2009 & & 2009 & & 2009 & \\
No. of workplaces & 1007 & & 1007 & & 1007 & \\
\hline
\end{tabular}


Table 8b: Disability diversity \& satisfaction with involvement in decision-making, nondisabled employees

\begin{tabular}{lllllll}
\hline & Model 1 & & $\begin{array}{l}\text { Model 2 } \\
\text { Coeff }\end{array}$ & z-stat & $\begin{array}{l}\text { Model 3 } \\
\text { Coeff }\end{array}$ & z-stat \\
\hline Disability Diversity & -1.081 & -2.03 & -0.864 & -1.65 & -0.667 & -1.27 \\
-Cut11 (Cons) & -2.634 & -24.45 & -2.612 & -16.18 & -2.561 & -15.89 \\
_Cut12 (Cons) & -0.710 & -6.72 & -0.684 & -4.28 & -0.633 & -3.96 \\
$\sigma^{\wedge}$ 2 (Workplace variance) & 0.587 & 22.63 & 0.551 & 21.72 & 0.544 & 21.44 \\
Log-Likelihood & -15384.822 & & -15324.676 & & -15314.059 & \\
No. of employees & 15142 & & 15142 & & 15142 & \\
No. of workplaces & 1440 & & 1440 & & 1440 & \\
\hline
\end{tabular}

\section{B. Disability diversity $\&$ affective well-being}

Table 9: Disability diversity and feeling not tense, past few weeks, all employees

\begin{tabular}{lllllll}
\hline & Model 1 & & Model 2 & & Model 3 & \\
& Coeff & z-stat & Coeff & z-stat & Coeff & z-stat \\
\hline Disability Diversity & -0.401 & -0.97 & -0.383 & -0.94 & -0.326 & -0.80 \\
-Cut11 (Cons) & -2.285 & -23.52 & -2.334 & -16.83 & -2.346 & -16.90 \\
_Cut12 (Cons) & -0.186 & -1.95 & -0.233 & -1.70 & -0.245 & -1.78 \\
$\sigma^{\wedge}$ (Workplace variance) & 0.389 & 16.36 & 0.368 & 15.42 & 0.364 & 15.20 \\
Log-Likelihood & -17235.550 & & -17203.695 & & -17197.787 & \\
No. of employees & 17151 & & 17151 & & 17151 & \\
No. of workplaces & 1441 & & 1441 & & 1441 & \\
\hline
\end{tabular}

Table 9a: Disability diversity and feeling not tense, past few weeks, disabled employees

\begin{tabular}{lllllll}
\hline & Model 1 & & Model 2 & & Model 3 & \\
& Coeff & z-stat & Coeff & z-stat & Coeff & z-stat \\
\hline Disability Diversity & 0.543 & 0.69 & 0.420 & 0.54 & 0.540 & 0.70 \\
-Cut11 (Cons) & -1.998 & -6.84 & -2.173 & -5.65 & -2.310 & -5.98 \\
_Cut12 (Cons) & 0.041 & 0.14 & -0.137 & -0.36 & -0.272 & -0.71 \\
$\sigma^{\wedge}$ 2 (Workplace variance) & 0.447 & 3.46 & 0.380 & 2.62 & 0.363 & 2.41 \\
Log-Likelihood & -2064.818 & & -2052.910 & & -2048.781 & \\
No. of employees & 2009 & & 2009 & & 2009 & \\
No. of workplaces & 1007 & & 1007 & & 1007 & \\
\hline
\end{tabular}

Table 9b: Disability diversity and feeling not tense, past few weeks, non-disabled employees

\begin{tabular}{lllllll}
\hline & Model 1 & & $\begin{array}{l}\text { Model 2 } \\
\text { Coeff }\end{array}$ & z-stat & $\begin{array}{l}\text { Model 3 } \\
\text { Coeff }\end{array}$ & z-stat \\
\hline Disability Diversity & -0.647 & -1.39 & -0.610 & -1.32 & -0.565 & -1.21 \\
-Cut11 (Cons) & -2.314 & -22.36 & -2.354 & -15.87 & -2.358 & -15.87 \\
_Cut12 (Cons) & -0.192 & -1.89 & -0.230 & -1.57 & -0.234 & -1.59 \\
$\sigma^{\wedge}$ (Workplace variance) & 0.417 & 16.31 & 0.398 & 15.54 & 0.395 & 15.38 \\
Log-Likelihood & -15154.414 & & -15126.189 & & -15122.229 & \\
No. of employees & 15142 & & 15142 & & 15142 & \\
No. of workplaces & 1440 & & 1440 & & 1440 & \\
\hline
\end{tabular}


Table 10: Disability diversity and feeling calm, past few weeks, all employees

\begin{tabular}{lllllll}
\hline & Model 1 & & Model 2 & & Model 3 & \\
& Coeff & z-stat & Coeff & z-stat & Coeff & z-stat \\
\hline Disability Diversity & -0.592 & -1.53 & -0.542 & -1.41 & -0.516 & -1.34 \\
_Cut11 (Cons) & -0.925 & -9.90 & -0.861 & -6.52 & -0.862 & -6.51 \\
_Cut12 (Cons) & 0.383 & 4.11 & 0.448 & 3.40 & 0.448 & 3.38 \\
$\sigma^{\wedge}$ 2 (Workplace variance) & 0.332 & 13.87 & 0.313 & 12.85 & 0.312 & 12.82 \\
Log-Likelihood & -18267.291 & & -18241.971 & & -18239.767 & \\
No. of employees & 17151 & & 17151 & & 17151 & \\
No. of workplaces & 1441 & & 1441 & & 1441 & \\
\hline
\end{tabular}

Table 10a: Disability diversity and feeling calm, past few weeks, disabled employees

\begin{tabular}{lllllll}
\hline & Model 1 & & Model 2 & & Model 3 & \\
& Coeff & z-stat & Coeff & z-stat & Coeff & z-stat \\
\hline Disability Diversity & 0.841 & 1.09 & 0.999 & 1.33 & 0.995 & 1.33 \\
-Cut11 (Cons) & -0.762 & -2.66 & -0.828 & -2.21 & -0.858 & -2.27 \\
_Cut12 (Cons) & 0.530 & 1.85 & 0.460 & 1.23 & 0.429 & 1.14 \\
$\sigma^{\wedge}$ 2 (Workplace variance) & 0.412 & 3.12 & 0.310 & 1.93 & 0.300 & 1.82 \\
Log-Likelihood & -2085.166 & & -2070.912 & & -2070.338 & \\
No. of employees & 2009 & & 2009 & & 2009 & \\
No. of workplaces & 1007 & & 1007 & & 1007 & \\
\hline
\end{tabular}

Table 10b: Disability diversity and feeling calm, past few weeks, non-disabled employees

\begin{tabular}{lllllll}
\hline & Model 1 & & Model 2 & & Model 3 & \\
& Coeff & z-stat & Coeff & z-stat & Coeff & z-stat \\
\hline Disability Diversity & -0.956 & -2.22 & -0.940 & -2.19 & -0.911 & -2.11 \\
-Cut11 (Cons) & -0.926 & -9.36 & -0.849 & -6.09 & -0.846 & -6.05 \\
_Cut12 (Cons) & 0.389 & 3.94 & 0.467 & 3.35 & 0.470 & 3.37 \\
$\sigma^{\wedge}$ 2 (Workplace variance) & 0.335 & 12.80 & 0.318 & 11.94 & 0.317 & 11.86 \\
Log-Likelihood & -16169.606 & & -16148.467 & & -16145.987 & \\
No. of employees & 15142 & & 15142 & & 15142 & \\
No. of workplaces & 1440 & & 1440 & & 1440 & \\
\hline
\end{tabular}

Table 11: Disability diversity and feeling relaxed, past few weeks, all employees

\begin{tabular}{lllllll}
\hline & Model 1 & & Model 2 & & Model 3 & \\
& Coeff & z-stat & Coeff & z-stat & Coeff & z-stat \\
\hline Disability Diversity & -0.423 & -1.05 & -0.338 & -0.85 & -0.250 & -0.63 \\
_Cut11 (Cons) & -0.478 & -5.02 & -0.374 & -2.78 & -0.382 & -2.83 \\
_Cut12 (Cons) & 0.806 & 8.44 & 0.911 & 6.75 & 0.904 & 6.69 \\
$\sigma^{\wedge}$ 2 (Workplace variance) & 0.359 & 14.99 & 0.333 & 13.65 & 0.330 & 13.49 \\
Log-Likelihood & -17591.002 & & -17553.105 & & -17548.233 & \\
No. of employees & 17151 & & 17151 & & 17151 & \\
No. of workplaces & 1441 & & 1441 & & 1441 & \\
\hline
\end{tabular}


Table 11a: Disability diversity and feeling relaxed, past few weeks, disabled employees

\begin{tabular}{lllllll}
\hline & Model 1 & & Model 2 & & Model 3 & \\
& Coeff & z-stat & Coeff & z-stat & Coeff & z-stat \\
\hline Disability Diversity & 0.138 & 0.18 & 0.304 & 0.39 & 0.321 & 0.41 \\
-Cut11 (Cons) & -0.229 & -0.80 & -0.248 & -0.66 & -0.302 & -0.79 \\
_Cut12 (Cons) & 1.064 & 3.68 & 1.044 & 2.76 & 0.990 & 2.60 \\
$\sigma^{\wedge}$ 2 (Workplace variance) & 0.345 & 2.31 & 0.209 & 0.92 & 0.188 & 0.75 \\
Log-Likelihood & -1978.811 & & -1960.961 & & -1959.589 & \\
No. of employees & 2009 & & 2009 & & 2009 & \\
No. of workplaces & 1007 & & 1007 & & 1007 & \\
\hline
\end{tabular}

Table 11b: Disability diversity and feeling relaxed, past few weeks, non-disabled employees

\begin{tabular}{lllllll}
\hline & $\begin{array}{l}\text { Model 1 } \\
\text { Coeff }\end{array}$ & z-stat & $\begin{array}{l}\text { Model 2 } \\
\text { Coeff }\end{array}$ & z-stat & $\begin{array}{l}\text { Model 3 } \\
\text { Coeff }\end{array}$ & z-stat \\
\hline Disability Diversity & -0.503 & -1.14 & -0.448 & -1.02 & -0.340 & -0.77 \\
_Cut11 (Cons) & -0.495 & -4.91 & -0.374 & -2.64 & -0.374 & -2.64 \\
_Cut12 (Cons) & 0.789 & 7.82 & 0.911 & 6.42 & 0.911 & 6.41 \\
$\sigma^{\wedge}$ 2 (Workplace variance) & 0.357 & 13.50 & 0.334 & 12.41 & 0.330 & 12.21 \\
Log-Likelihood & -15610.047 & & -15577.445 & & -15572.294 & \\
No. of employees & 15142 & & 15142 & & 15142 & \\
No. of workplaces & 1440 & & 1440 & & 1440 & \\
\hline
\end{tabular}

Table 12: Disability diversity and feeling not worried, past few weeks, all employees

\begin{tabular}{lllllll}
\hline & Model 1 & & Model 2 & & Model 3 & \\
& Coeff & z-stat & Coeff & z-stat & Coeff & z-stat \\
\hline Disability Diversity & -0.493 & -1.25 & -0.474 & -1.21 & -0.421 & -1.08 \\
_Cut11 (Cons) & -2.616 & -26.09 & -2.586 & -18.86 & -2.604 & -18.96 \\
_Cut12 (Cons) & -0.539 & -5.50 & -0.508 & -3.75 & -0.526 & -3.87 \\
$\sigma^{\wedge}$ 2 (Workplace variance) & 0.299 & 10.92 & 0.272 & 9.52 & 0.268 & 9.24 \\
Log-Likelihood & -15730.611 & & -15702.173 & & -15698.214 & \\
No. of employees & 17151 & & 17151 & & 17151 & \\
No. of workplaces & 1441 & & 1441 & & 1441 & \\
\hline
\end{tabular}

Table 12a: Disability diversity and feeling not worried, past few weeks, disabled employees

\begin{tabular}{lllllll}
\hline & Model 1 & & Model 2 & & Model 3 & \\
& Coeff & z-stat & Coeff & z-stat & Coeff & z-stat \\
\hline Disability Diversity & 0.295 & 0.39 & 0.249 & 0.33 & 0.313 & 0.42 \\
-Cut11 (Cons) & -1.836 & -6.32 & -1.952 & -5.14 & -2.023 & -5.30 \\
_Cut12 (Cons) & 0.093 & 0.32 & -0.021 & -0.06 & -0.093 & -0.25 \\
$\sigma^{\wedge}$ 2 (Workplace variance) & 0.237 & 1.11 & 0.159 & 0.52 & 0.123 & 0.32 \\
Log-Likelihood & -1924.950 & & -1915.263 & & -1913.643 & \\
No. of employees & 2009 & & 2009 & & 2009 & \\
No. of workplaces & 1007 & & 1007 & & 1007 & \\
\hline
\end{tabular}


Table 12b: Disability diversity and feeling not worried, past few weeks, non-disabled employees

\begin{tabular}{lllllll}
\hline & Model 1 & & Model 2 & & Model 3 & \\
& Coeff & z-stat & Coeff & z-stat & Coeff & z-stat \\
\hline Disability Diversity & -0.701 & -1.57 & -0.654 & -1.48 & -0.607 & -1.37 \\
_Cut11 (Cons) & -2.696 & -25.21 & -2.656 & -18.17 & -2.669 & -18.22 \\
_Cut12 (Cons) & -0.591 & -5.67 & -0.551 & -3.82 & -0.563 & -3.90 \\
$\sigma^{\wedge}$ (Workplace variance) & 0.315 & 10.57 & 0.287 & 9.28 & 0.283 & 9.04 \\
Log-Likelihood & -13788.074 & & -13760.204 & & -13756.683 & \\
No. of employees & 15142 & & 15142 & & 15142 & \\
No. of workplaces & 1440 & & 1440 & & 1440 & \\
\hline
\end{tabular}

Table 13: Disability diversity and feeling not uneasy, past few weeks, all employees

\begin{tabular}{lllllll}
\hline & Model 1 & & Model 2 & & Model 3 \\
& Coeff & z-stat & Coeff & z-stat & Coeff & z-stat \\
\hline Disability Diversity & -0.782 & -1.91 & -0.659 & -1.61 & -0.596 & -1.45 \\
-Cut11 (Cons) & -2.805 & -26.60 & -2.671 & -18.40 & -2.686 & -18.47 \\
_Cut12 (Cons) & -0.932 & -9.06 & -0.797 & -5.56 & -0.812 & -5.66 \\
$\sigma^{\wedge}$ 2 (Workplace variance) & 0.322 & 11.59 & 0.307 & 10.87 & 0.302 & 10.62 \\
Log-Likelihood & -14544.562 & & -14525.596 & & -14521.019 & \\
No. of employees & 17151 & & 17151 & & 17151 & \\
No. of workplaces & 1441 & & 1441 & & 1441 &
\end{tabular}

Table 13a: Disability diversity and feeling not uneasy, past few weeks, disabled employees

\begin{tabular}{lllllll}
\hline & Model 1 & & Model 2 & & Model 3 \\
& Coeff & z-stat & Coeff & z-stat & Coeff & z-stat \\
\hline Disability Diversity & 0.224 & 0.28 & 0.282 & 0.34 & 0.389 & 0.47 \\
-Cut11 (Cons) & -2.331 & -7.52 & -2.514 & -6.17 & -2.592 & -6.31 \\
_Cut12 (Cons) & -0.461 & -1.53 & -0.648 & -1.62 & -0.725 & -1.79 \\
$\sigma^{\wedge}$ 2 (Workplace variance) & 0.391 & 2.49 & 0.348 & 2.02 & 0.342 & 1.95 \\
Log-Likelihood & -1801.420 & & -1796.650 & & -1795.161 & \\
No. of employees & 2009 & & 2009 & & 2009 & \\
No. of workplaces & 1007 & & 1007 & & 1007 & \\
\hline
\end{tabular}

Table 13b: Disability diversity and feeling not uneasy, past few weeks, non-disabled employees

\begin{tabular}{lllllll}
\hline & Model 1 & & Model 2 & & Model 3 & \\
& Coeff & z-stat & Coeff & z-stat & Coeff & z-stat \\
\hline Disability Diversity & -1.070 & -2.30 & -0.951 & -2.05 & -0.904 & -1.94 \\
-Cut11 (Cons) & -2.851 & -25.29 & -2.677 & -17.25 & -2.689 & -17.30 \\
_Cut12 (Cons) & -0.966 & -8.79 & -0.791 & -5.16 & -0.803 & -5.23 \\
$\sigma^{\wedge}$ (Workplace variance) & 0.347 & 11.78 & 0.330 & 11.00 & 0.325 & 10.76 \\
Log-Likelihood & -12721.932 & & -12701.426 & & -12697.330 & \\
No. of employees & 15142 & & 15142 & & 15142 & \\
No. of workplaces & 1440 & & 1440 & & 1440 & \\
\hline
\end{tabular}


Table 14: Disability diversity and feeling content, past few weeks, all employees

\begin{tabular}{lllllll}
\hline & Model 1 & & Model 2 & & Model 3 \\
& Coeff & z-stat & Coeff & z-stat & Coeff & z-stat \\
\hline Disability Diversity & -0.671 & -1.64 & -0.495 & -1.22 & -0.388 & -0.96 \\
-Cut11 (Cons) & -1.334 & -14.08 & -1.137 & -8.39 & -1.129 & -8.31 \\
-Cut12 (Cons) & 0.005 & 0.06 & 0.204 & 1.51 & 0.212 & 1.57 \\
$\sigma^{\wedge}$ 2 (Workplace variance) & 0.391 & 17.08 & 0.364 & 15.85 & 0.363 & 15.78 \\
Log-Likelihood & -18284.666 & & -18237.742 & & -18233.902 & \\
No. of employees & 17151 & & 17151 & & 17151 & \\
No. of workplaces & 1441 & & 1441 & & 1441 & \\
\hline
\end{tabular}

Table 14a: Disability diversity and feeling content, past few weeks, disabled employees

\begin{tabular}{lllllll}
\hline & Model 1 & & Model 2 & & Model 3 & \\
& Coeff & z-stat & Coeff & z-stat & Coeff & z-stat \\
\hline Disability Diversity & 0.141 & 0.17 & 0.369 & 0.46 & 0.464 & 0.57 \\
-Cut11 (Cons) & -1.447 & -4.90 & -1.328 & -3.43 & -1.409 & -3.61 \\
_Cut12 (Cons) & -0.110 & -0.38 & -0.001 & 0.00 & -0.080 & -0.21 \\
$\sigma^{\wedge}$ 2 (Workplace variance) & 0.560 & 4.93 & 0.452 & 3.47 & 0.452 & 3.49 \\
Log-Likelihood & -2093.455 & & -2078.281 & & -2076.264 & \\
No. of employees & 2009 & & 2009 & & 2009 & \\
No. of workplaces & 1007 & & 1007 & & 1007 & \\
\hline
\end{tabular}

Table 14b: Disability diversity and feeling content, past few weeks, non-disabled employees

\begin{tabular}{lllllll}
\hline & Model 1 & & Model 2 & & Model 3 & \\
& Coeff & z-stat & Coeff & z-stat & Coeff & z-stat \\
\hline Disability Diversity & -0.872 & -1.95 & -0.744 & -1.68 & -0.636 & -1.43 \\
_Cut11 (Cons) & -1.304 & -13.04 & -1.097 & -7.73 & -1.082 & -7.61 \\
_Cut12 (Cons) & 0.041 & 0.41 & 0.251 & 1.77 & 0.265 & 1.87 \\
$\sigma^{\wedge}$ 2 (Workplace variance) & 0.380 & 15.00 & 0.355 & 13.93 & 0.353 & 13.85 \\
Log-Likelihood & -16187.687 & & -16144.291 & & -16140.787 & \\
No. of employees & 15142 & & 15142 & & 15142 & \\
No. of workplaces & 1440 & & 1440 & & 1440 & \\
\hline
\end{tabular}




\section{Selected facets of satisfaction related results based on discrete measures of workplace disability diversity}

Table 2c: Disability diversity and satisfaction with the scope for using own initiative, nondisabled employees

\begin{tabular}{lllllll}
\hline & Model 1 & & Model 2 & & Model 3 \\
& Coeff & z-stat & Coeff & z-stat & Coeff & z-stat \\
\hline Disability Diversity2 & -0.128 & -2.06 & -0.086 & -1.37 & -0.066 & -1.05 \\
Disability Diversity3 & -0.129 & -1.67 & -0.147 & -1.92 & -0.134 & -1.74 \\
-Cut11 (Cons) & -2.955 & -23.18 & -2.868 & -16.19 & -2.860 & -16.09 \\
_Cut12 (Cons) & -1.583 & -12.64 & -1.494 & -8.51 & -1.486 & -8.44 \\
$\sigma^{\wedge}$ 2 (Workplace variance) & 0.435 & 13.64 & 0.409 & 12.65 & 0.408 & 12.60 \\
Log-Likelihood & -10958.833 & & -10923.221 & & -10921.408 & \\
No. of employees & 15142 & & 15142 & & 15142 & \\
No. of workplaces & 1440 & & 1440 & & 1440 & \\
\hline
\end{tabular}

Table 3c: Disability diversity and satisfaction with the amount of influence over the job, non-disabled employees

\begin{tabular}{lllllll}
\hline & Model 1 & & Model 2 & & Model 3 & \\
& Coeff & z-stat & Coeff & z-stat & Coeff & z-stat \\
\hline Disability Diversity2 & -0.130 & -2.26 & -0.066 & -1.16 & -0.039 & -0.68 \\
Disability Diversity3 & -0.191 & -2.70 & -0.200 & -2.90 & -0.183 & -2.64 \\
_Cut11 (Cons) & -2.745 & -24.41 & -2.583 & -16.42 & -2.568 & -16.28 \\
_Cut12 (Cons) & -1.108 & -10.04 & -0.944 & -6.06 & -0.929 & -5.94 \\
$\sigma^{\wedge}$ 2 (Workplace variance) & 0.436 & 16.07 & 0.398 & 14.42 & 0.395 & 14.32 \\
Log-Likelihood & -13633.846 & & -13583.057 & & -13578.934 & \\
No. of employees & 15142 & & 15142 & & 15142 & \\
No. of workplaces & 1440 & & 1440 & & 1440 & \\
\hline
\end{tabular}

Table 6c: Disability diversity and satisfaction with job security, non-disabled employees

\begin{tabular}{lllllll}
\hline & Model 1 & & Model 2 & \multicolumn{3}{c}{ Model 3 } \\
& Coeff & z-stat & Coeff & z-stat & Coeff & z-stat \\
\hline Disability Diversity2 & -0.166 & -1.80 & -0.110 & -1.23 & -0.089 & -0.98 \\
Disability Diversity3 & -0.290 & -2.61 & -0.306 & -2.88 & -0.291 & -2.73 \\
_Cut11 (Cons) & -1.352 & -11.22 & -0.962 & -4.67 & -0.957 & -4.63 \\
-Cut12 (Cons) & 0.124 & 1.03 & 0.515 & 2.50 & 0.520 & 2.52 \\
$\sigma^{\wedge}$ 2 (Workplace variance) & 0.975 & 30.65 & 0.895 & 29.42 & 0.895 & 29.41 \\
Log-Likelihood & -12618.649 & & -12534.795 & & -12533.284 & \\
No. of employees & 15142 & & 15142 & & 15142 & \\
No. of workplaces & 1440 & & 1440 & & 1440 & \\
\hline
\end{tabular}




\section{Selected affective well-being related results based on discrete measures of workplace disability diversity}

Table 10c: Disability diversity and feeling calm, past few weeks, non-disabled employees

\begin{tabular}{lllllll}
\hline & Model 1 & & Model 2 & \multicolumn{3}{c}{ Model 3 } \\
& Coeff & z-stat & Coeff & z-stat & Coeff & z-stat \\
\hline Disability Diversity2 & -0.065 & -1.30 & -0.048 & -0.95 & -0.040 & -0.77 \\
Disability Diversity3 & -0.101 & -1.62 & -0.104 & -1.69 & -0.100 & -1.61 \\
-Cut11 (Cons) & -0.929 & -9.36 & -0.849 & -6.08 & -0.845 & -6.03 \\
_Cut12 (Cons) & 0.386 & 3.90 & 0.467 & 3.34 & 0.471 & 3.36 \\
$\sigma^{\wedge}$ 2 (Workplace variance) & 0.337 & 12.88 & 0.320 & 12.02 & 0.318 & 11.94 \\
Log-Likelihood & -16170.195 & & -16149.201 & & -16146.794 & \\
No. of employees & 15142 & & 15142 & & 15142 & \\
No. of workplaces & 1440 & & 1440 & & 1440 & \\
\hline
\end{tabular}

Table 13c: Disability diversity and feeling not uneasy, past few weeks, non-disabled employees

\begin{tabular}{lllllll}
\hline & Model 1 & & Model 2 & & Model 3 \\
& Coeff & z-stat & Coeff & z-stat & Coeff & z-stat \\
\hline Disability Diversity2 & -0.019 & -0.35 & -0.004 & -0.08 & 0.004 & 0.07 \\
Disability Diversity3 & -0.133 & -1.97 & -0.129 & -1.92 & -0.122 & -1.81 \\
_Cut11 (Cons) & -2.848 & -25.19 & -2.674 & -17.20 & -2.684 & -17.24 \\
_Cut12 (Cons) & -0.963 & -8.74 & -0.788 & -5.13 & -0.798 & -5.19 \\
$\sigma^{\wedge}$ 2 (Workplace variance) & 0.347 & 11.78 & 0.330 & 11.00 & 0.325 & 10.76 \\
Log-Likelihood & -12722.616 & & -12701.642 & & -12697.486 & \\
No. of employees & 15142 & & 15142 & & 15142 & \\
No. of workplaces & 1440 & & 1440 & & 1440 & \\
\hline
\end{tabular}




\section{References}

Abowd, J., Kramarz, F. and Margolis, D.(1999) High wage workers and high wage firms, Econometrica, 67 (2), 251-333.

Aigner, D. and Cain, G. (1977) Statistical Theories of Discrimination in Labour Markets, Industrial and Labour Relations Review, 30 (2), 175-187.

Akerlof, G. A. and Kranton, R. E. (2000) Economics and Identity, The Quarterly Journal of Economics, 115 (3), 715-753.

Arrow, K. (1972) Models of Job Discrimination. In Pascal, A (ed.) Racial Discrimination in Economic Life, Lexington, Massachusetts: D. C. Heath and Co.

Arrow, K. (1973) The theory of Discrimination. In Ashenfelter \& Rees (eds.)

Discrimination in Labor Markets, Princeton: Princeton University Press.

Becker, G. (1971) The Economics of Discrimination, University of Chicago Press.

Berthoud, R. (2006) The Employment Rates of Disabled People, DWP Research Report 298.

London: Department for Work and Pensions

Berthoud, R. (2008) Disability employment penalties in Britain, Work Employment Society, 22 (1), $129-148$.

Berthoud, R. and Blekesaune, M. (2007) Persistent Employment Disadvantage, DWP Research Report 416. London: Department for Work and Pensions.

Blau, P. M. (1977) Inequality and Heterogeneity. New York: Free Press.

Blau, P. M. (1977), Inequality and heterogeneity, New York: Free Press

Blekesaune, M. (2007) Have Some European Countries Been More Successful At Employing Disabled People Than Others? ISER Working Paper 2007-23

CIPD(2003) Managing employee careers: Issues, trends and prospects, Survey report, London: Chartered Institute of Personnel and Development

Crouchley, R. (1995) A Random-Effects Model for Ordered Categorical Data, Journal of the American Statistical Association, 90 (430), 489-498.

Daniels, K (2000), Measures of five aspects of affective well-being at work, Human Relations, 53 (2), 275 - 294.

Disney, R., Emmerson, C. and Wakefield, M. (2006) Ill health and retirement in Britain: a panel data-based analysis, Journal of Health Economics, 25, 621-649.

EHRC (2008) Insight: Work fit for all - disability, health and the experience of negative treatment in the British workplace.

Ferrer- $i$-Carbonell, A. and Frijters, P., (2004) How important is methodology for the estimates of the determinants of happiness, The Economic Journal, 114, 641-659.

Harrison, D. A. and Sin, Hock-Peng (2006), What is Diversity and How Should It Be Measured? In Konard, A. M., Prasad, P. and Pringle, J. (eds.), Handbook of Workplace Diversity, Sage Publications Inc., London.

Hedeker, D. and Gibbons, R. (1994) A Random-Effects Ordinal Regression Model for Multilevel Analysis, Biometrics, 50, 933-944.

Hoque K and Noon M (2004) Equal opportunities policy and practice in Britain: evaluating the 'empty shell' hypothesis. Work, employment and society, 18 (3), 481506.

Jackson, S.E., Joshi, A., and Erhardt, N.L. (2003) Recent research on team and organizational diversity: SWOT analysis and implications, Journal of Management, 29(6), 801-830.

Jehn, K.A., Northcraft, G.B. and Neale, M.A. (1999) Why difference makes a difference: a field study of diversity, conflict, and performance in workgroups. Administrative Science Quarterly, 44, 741-63.

Jones, M. K., Latreille, P. L. and Sloane, P. J. (2003) Disability, Gender and the Labour Market, IZA Discussion Paper No. 936. 
Kochan T, Bezrukova K, Ely R, Jackson S, Joshi A, Jehn K, Leonard J, Levine D and Thomas D (2003) The Effects of Diversity on Business Performance: Report of the Diversity Research Work. Human Resource Management, 42 (1), 3-21.

Lang, K. (1986) A Language Theory of Discrimination, The Quarterly Journal of Economics, May 1986, 101 (2), 363-382.

Lazear, E. (1999) Globalisation and the market for team-mates, The Economic Journal, 109, C15-C40.

Leonard, J.S. and Levine, D.I. (2006), The Effect of Diversity on Turnover: A Large Case Study. Industrial \& Labor Relations Review, 59 (4), 547-572.

Madden, D. (2004) Labour market discrimination on the basis of health: an application to UK data, Applied Economics, 36, 421-442.

Maume, D. J. and Sebastian, R. (2007) Racial Composition of Workgroups and Job Satisfaction among Whites, The ANNALS of the American Academy of Political and Social Sciences, 609, 85-103.

$\mathrm{Ng}, \mathrm{Y}-\mathrm{K}$ (1997) A case for happiness, cardinalism, and interpersonal comparability, The Economic Journal, 107, 1848-1858.

Pelled, L.H., Eisenhardt, K.M. and Xin, K.R. (1999) Exploring the black box: an analysis of work group diversity, conflict, and performance, Administrative Science Quarterly, 44(1), 1-26.

Perotin V. and Robinson A. (2000) Employee Participation and Equal Opportunities Practices: Productivity Effect and Potential Complementarities. British Journal of Industrial Relations, 38 (4), 557-583.

Pfeffer, J. (1983) Organizational Demography, in Research in Organizational Behaviour, 5, L. L. Cummings and B. M. Staw (eds.), JAI Press, Greenwich, 299-357.

Phelps, E. S. (1972), The statistical theory of racism and sexism, American Economic Review, 62, 659-661.

Rabe-Hesketh, S. and Skrondal, A. (2008) Multilevel and Longitudinal Modelling Using Stata. StataCorp LP, College Station, Texas.

Ragan, J. F. and Tremblay, C. H. (1988) Testing for Employee Discrimination by Race and Sex. The Journal of Human Resources, 23 (1), 123-137.

Rode, J. (2004) Job Satisfaction and life satisfaction revisited: a longitudinal test of an integrated model. Human Relations, 57 (9), 1205 - 1230.

Rodriguez, G and Goldman, N (2001) An Assessment of Estimation Procedures for Multilevel Models with Binary Responses, Journal of the Royal Statistical Society. Series A (Statistics in Society), 158 (1), 73-89.

Skrondal, A. and Rabe-Hesketh, S. (2004) Generalised Latent V ariable Modelling: Multilevel, Longitudinal, and Structural Equation Models, Chapman \& Hall/CRC.

Snijders, T. and Bosker, R. (2004) Multilevel Analysis: An introduction to basic and advanced multilevel modelling, Sage Publications Ltd, London

Stone-Romero, E., Stone, D. and Lukaszewshi, K (2006) The Influence of Disability on Role-Taking in Organizations, in Konard, A., Prasad, P. and Pringle, J. (eds.) Handbook of Workplace Diversity, Sage Publications Ltd, London.

Warr, P. (194), Conceptual framework for the study of work and mental health, Work and Stress, 8, $84-97$.

Warr, P. (1999), Well-being and the Workplace, in Kahneman, D., Diener, E. and Schwarz, N. (eds.), Well-being: the foundations of hedonic psychology, Russell Sage Foundation, New York.

White M, Hill S, Mills C and Smeaton D (2004) Managing to Change? British Workplaces and the Future of $W$ ork, Palgrave Macmillan.

Wooldridge, J. M. (2002) Econometric Analysis of Cross Section and Panel Data, Massachusetts Institute of Technology. 


\section{Appendix}

Figure A1: Workplace disability diversity, WERS2004

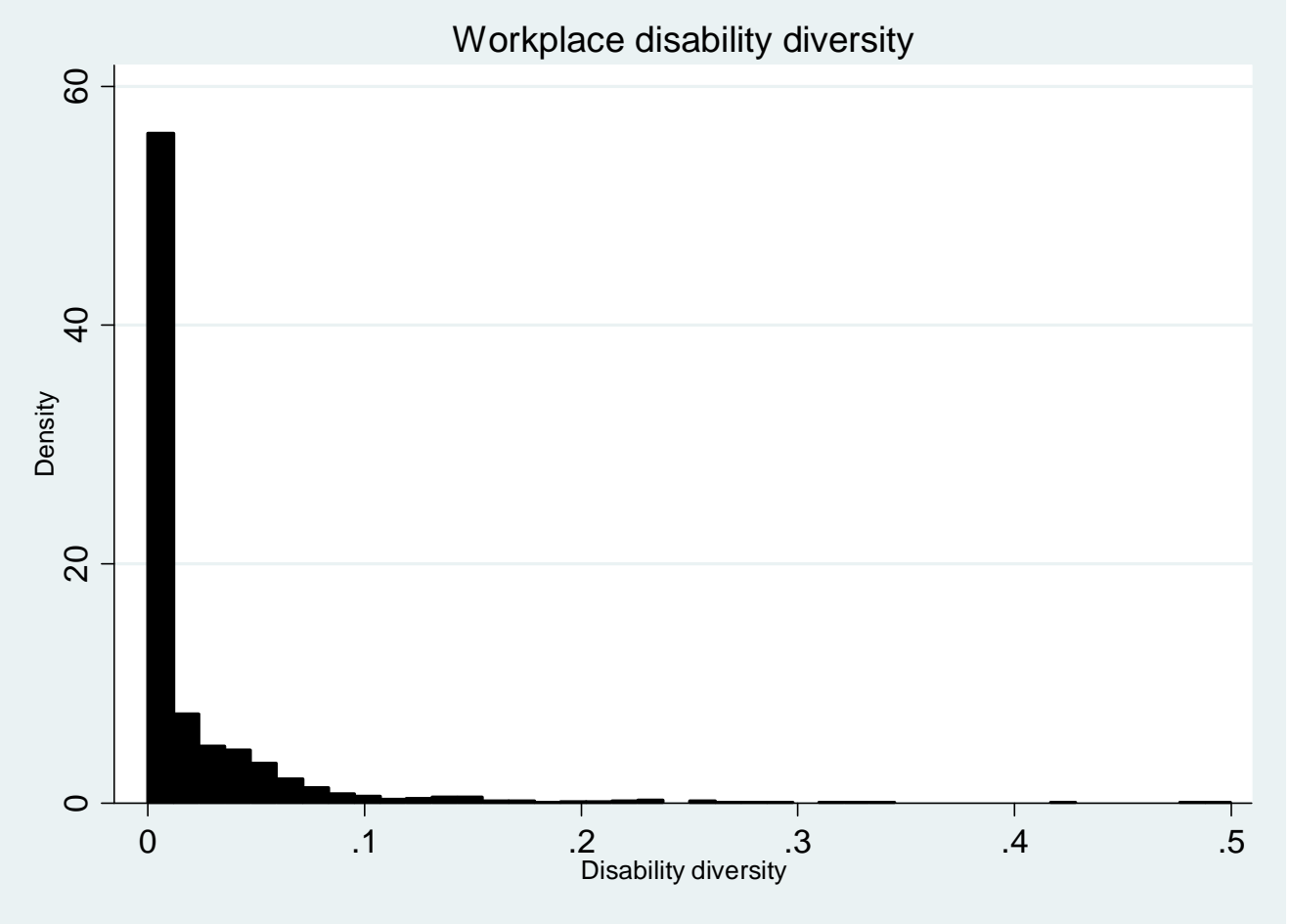

Table A1: Descriptive statistics, job-related well-being outcome measures $(N=17151)$

\begin{tabular}{lcccc} 
& Mean & Std. Dev. & Min & Max \\
\hline Facet of Satisfaction: & & & & \\
Achievement & 2.613 & 0.660 & 1 & 3 \\
Initiative & 2.627 & 0.656 & 1 & 3 \\
Influence & 2.446 & 0.723 & 1 & 3 \\
Training & 2.283 & 0.807 & 1 & 3 \\
Pay & 1.968 & 0.870 & 1 & 3 \\
Job security & 2.476 & 0.745 & 1 & 3 \\
Work itself & 2.636 & 0.643 & 1 & 3 \\
Decision & 2.177 & 0.765 & 1 & 3 \\
$\quad$ Affective well-being & & & & \\
Not tense & 2.200 & 0.731 & 1 & 3 \\
Calm & 1.949 & 0.838 & 1 & 3 \\
Relaxed & 1.776 & 0.822 & 1 & 3 \\
Not worried & 2.403 & 0.690 & 1 & 3 \\
Not uneasy & 2.526 & 0.661 & 1 & 3 \\
Content & 2.059 & 0.834 & 1 & 3 \\
\hline
\end{tabular}


Table A2: Correlation matrix, job-related well-being measures in Table A1 ( $N=17151)$

\begin{tabular}{|c|c|c|c|c|c|c|c|c|c|c|c|c|c|c|}
\hline & Ach & $\operatorname{Ini}$ & $\operatorname{Inf}$ & Tra & Pay & Jse & Wrk & Dec & Nte & Cal & $\mathrm{Rel}$ & Nwo & Nun & Con \\
\hline Achievement & 1 & & & & & & & & & & & & & \\
\hline Initiative & 0.57 & 1 & & & & & & & & & & & & \\
\hline Influence & 0.53 & 0.66 & 1 & & & & & & & & & & & \\
\hline Training & 0.30 & 0.30 & 0.36 & 1 & & & & & & & & & & \\
\hline Pay & 0.21 & 0.21 & 0.25 & 0.28 & 1 & & & & & & & & & \\
\hline Job security & 0.27 & 0.26 & 0.31 & 0.31 & 0.25 & 1 & & & & & & & & \\
\hline Work itself & 0.62 & 0.47 & 0.47 & 0.30 & 0.22 & 0.30 & 1 & & & & & & & \\
\hline Decision & 0.39 & 0.44 & 0.51 & 0.36 & 0.31 & 0.30 & 0.36 & 1 & & & & & & \\
\hline Not tense & 0.18 & 0.13 & 0.17 & 0.18 & 0.13 & 0.16 & 0.21 & 0.16 & 1 & & & & & \\
\hline Calm & 0.24 & 0.20 & 0.25 & 0.22 & 0.16 & 0.21 & 0.27 & 0.21 & 0.50 & 1 & & & & \\
\hline Relaxed & 0.23 & 0.19 & 0.24 & 0.23 & 0.15 & 0.21 & 0.25 & 0.21 & 0.48 & 0.78 & 1 & & & \\
\hline Not worried & 0.14 & 0.10 & 0.14 & 0.14 & 0.10 & 0.17 & 0.18 & 0.11 & 0.60 & 0.38 & 0.37 & 1 & & \\
\hline Not uneasy & 0.23 & 0.18 & 0.22 & 0.19 & 0.14 & 0.23 & 0.26 & 0.19 & 0.54 & 0.36 & 0.34 & 0.69 & 1 & \\
\hline Content & 0.42 & 0.34 & 0.37 & 0.30 & 0.23 & 0.28 & 0.43 & 0.33 & 0.39 & 0.57 & 0.57 & 0.32 & 0.36 & 1 \\
\hline
\end{tabular}

Table 3A: Descriptive statistics, control variables $(N=17151)$

\begin{tabular}{lcccc} 
& & Std. & & \\
& Mean & Dev. & Min & Max \\
\hline Disability diversity & 0.020 & 0.044 & 0 & 0.5 \\
$\quad$ Employee characteristics: & & & & \\
Age<30 & 0.217 & 0.412 & 0 & 1 \\
Age30-39 & 0.257 & 0.437 & 0 & 1 \\
Age50-59 & 0.216 & 0.412 & 0 & 1 \\
Age60+ & 0.042 & 0.200 & 0 & 1 \\
Female & 0.521 & 0.500 & 0 & 1 \\
Married & 0.683 & 0.465 & 0 & 1 \\
White & 0.950 & 0.218 & 0 & 1 \\
Children <7yrs old & 0.182 & 0.386 & 0 & 1 \\
Other dependents & 0.160 & 0.367 & 0 & 1 \\
Disabled & 0.117 & 0.322 & 0 & 1 \\
No academic qual. & 0.149 & 0.356 & 0 & 1 \\
O-level & 0.232 & 0.422 & 0 & 1 \\
A-level & 0.091 & 0.288 & 0 & 1 \\
Other qualification & 0.325 & 0.469 & 0 & 1 \\
Missing qualification & 0.013 & 0.113 & 0 & 1 \\
On permanent contract & 0.922 & 0.268 & 0 & 1 \\
Full-time & 0.787 & 0.409 & 0 & 1 \\
Work over 48 hrs & 0.473 & 0.499 & 0 & 1 \\
Skill req. is higher & 0.531 & 0.499 & 0 & 1 \\
Skill req. is lower & 0.048 & 0.213 & 0 & 1 \\
Prof. occupations & 0.123 & 0.329 & 0 & 1 \\
Associate prof. or tech. & 0.160 & 0.367 & 0 & 1 \\
Admin \& secretarial & 0.186 & 0.389 & 0 & 1 \\
Skilled trades & 0.069 & 0.254 & 0 & 1 \\
Personnel services & 0.089 & 0.285 & 0 & 1 \\
Sales \& customer services & 0.067 & 0.250 & 0 & 1 \\
Process, plant, mach. op. & 0.077 & 0.267 & 0 & 1 \\
Elementary occupations & 0.101 & 0.301 & 0 & 1 \\
Trade union member & & 0.478 & 0 & 1 \\
Log workplace characteristics: & & 1.127 & 0 & 6.80 \\
Private establishment & 0.456 & 0 & 1 \\
Sole establishment & & & 0 & 1
\end{tabular}




\begin{tabular}{lcccc} 
No. of employees & 327.59 & 684.48 & 5 & 6292 \\
Manufacturing & 0.154 & 0.361 & 0 & 1 \\
Construction & 0.054 & 0.227 & 0 & 1 \\
Whole sale \& retail Trade & 0.096 & 0.294 & 0 & 1 \\
Hotel, rest \& transport & 0.096 & 0.294 & 0 & 1 \\
Public \& comm. services & 0.153 & 0.360 & 0 & 1 \\
Education & 0.125 & 0.331 & 0 & 1 \\
Health & 0.146 & 0.353 & 0 & 1 \\
Prop. (22+) on min. wage & 0.014 & 0.084 & 0 & 1 \\
Prop. in customer service & 0.108 & 0.236 & 0 & 1 \\
Urban area & 0.821 & 0.384 & 0 & 1 \\
Unemployment to vacancy ratio & 3.403 & 2.408 & 0 & 10 \\
Hpws (equality) & 0.120 & 0.937 & -2.44 & 1.19 \\
Hpws (training) & 0.044 & 0.971 & -1.60 & 2.71 \\
Hpws (flexibility) & 0.006 & 0.981 & -2.35 & 2.28 \\
\hline No. of employees & 17151 & & & \\
No. of establishments & 1440 & & & \\
\hline
\end{tabular}

Table A4: KMO and Bartlett's Test

\begin{tabular}{|c|c|c|}
\hline \multicolumn{3}{|c|}{ Kaiser-Meyer-Olkin Measure of Sampling } \\
\hline \multirow{3}{*}{$\begin{array}{l}\text { Bartlett's Test of } \\
\text { Sphericity }\end{array}$} & Approx. Chi-Square & 32488.533 \\
\hline & df & 276 \\
\hline & Sig. & .000 \\
\hline
\end{tabular}

Note: Statistics obtained from SPSS based factor analysis on initial sample

Table A5: Rotated Component Matrix(a)

Workplace policy and practice variables:

Equality variables:

1. Explicit mention of racial equality $\quad .938$

2. Explicit mention of gender equality $\quad .938$

3. Explicit mention of disability equality $\quad .928$

4. Explicit mention of belief/religion equality $\quad .914$

5. Explicit mention of sexual equality $\quad .827$

6. Explicit mention of age equality $\quad .784$

7. Explicit mention of marital-status equality $\quad .766$

8. Whether workplace has formal EO/Diversity policy $\quad .757$

Training variables:

1. Training covered team working $\quad .755$

2. Training covered communication $\quad .750$

3. Training covered leadership skills $\quad .672$

4. Training covered problem solving methods $\quad .640$

5. Training covered reliability \& working to deadlines $\quad .577$

$\begin{array}{ll}\text { 6. Training covered customer service/liaison } & .539\end{array}$

7. Training covered computer training .523

8. Training covered quality control procedures

Flexible work arrangement variables:

1. Employee has the ability to change shift patterns $\quad .703$

2. Employee able to increase work hours $\quad .697$

3. Employee can work night shift $\quad .655$

4. Employee able to reduce work hours $\quad .642$

5. Employee can work compressed hours $\quad .588$

6. Workplace has schemes for working from home

Extraction Method: Principal Component Analysis. Rotation Method: Varimax with Kaiser Normalization.

a Rotation converged in 5 iterations.

Note: Statistics obtained from SPSS based factor analysis on initial sample 